\title{
Phylogenetic Analysis of the Subtribe Ageroniina with Special Emphasis on Hamadryas (Lepidoptera, Nymphalidae) with an Identification Key to the Species of Hamadryas
}

\author{
Luis Ricardo Murillo-Hiller \\ Zoocriadero de Mariposas, Escuela de Biología, Universidad de Costa Rica, 2060 San José, Costa Rica \\ Correspondence should be addressed to Luis Ricardo Murillo-Hiller, murillohiller@gmail.com \\ Received 4 November 2011; Accepted 14 December 2011 \\ Academic Editors: H. W. Cheng, S. Van Nouhuys, and S. P. Henzi
}

Copyright ( 2012 Luis Ricardo Murillo-Hiller. This is an open access article distributed under the Creative Commons Attribution License, which permits unrestricted use, distribution, and reproduction in any medium, provided the original work is properly cited.

A cladistic analysis of the genus Hamadryas was done in order to answer two questions: is the genus Hamadryas monophyletic and, what characters best define the different species groups of the genus? The computer programs WinClada ver. 1.00 .08 and Nona ver. 2.8 for phylogenetic analysis were used. The 20 species of Hamadryas were analyzed together with Ectima erycinoides, Batesia hypochlora and Panacea procilla; these four genera together form the sub-tribe Ageronina of the subfamily Biblidinae. These 23 species with a total of 66 characters were included in the data matrix: 43 of external morphology, two from the fore wing spiral organ (responsible for sound production), and 20 of the male genitalia. Three different analyses, including all of the non-Hamadryas, using each species as the out-group, were done in order to compare results. A fourth analysis, using only Ectima erycinoides as an out group, was done in order to verify and compare the species groups of Hamadryas Also, three different phylogenetic attributes were mapped: biogeography, palatability and capacity to produce sound signals. An identification key to all the species of Hamadryas was prepared. All the analysis done combining Hamadryas with the other three genera suggests that Hamadryas as currently defined is polyphyletic.

\section{Introduction}

The biodiversity on earth is so enormous that it would not be possible to study it, if it were not classified [1] and phylogenetic analyses of the species permit us to approach their evolutionary relationships in order to establish hypothetical species groups on which the classification can be based.

Hamadryas Hübner (1806) is composed of twenty species ranging from the southern United States to northern Argentina [2]. According to DeVries [3] it is distinguished from other butterfly genera by their spotted "calico" pattern on the upper side. Jenkins [4] on the other hand states that Hamadryas is a taxonomically confused genus which has been in great need of revision and highlights the lack of a detailed study to find consistently valid distinguishing characters.
This genus is well known for producing an audible clicking sound, an ability that has been reported for many but not all species. It has been suggested that this sound is used in courtship, defense, and territoriality [5-7]. It is produced through a modification of the internal walls of the forewing subcostal vein which consists of a spiral organ that ends in a tympanic membrane which in turn releases the sound into the air $[7,8]$.

In contrast to most of other nymphalid butterflies, this genus perches on tree trunks with the wings open against the substrate and the head downward $[3,4,7]$. The reason for this particular behavior may be to increase crypsis because the butterfly's color pattern greatly resembles tree trunks; resting head-downward could make escaping from predators faster since a small jump takes the butterfly into a flying position with little energy cost [7]. Only two other genera 
of Nymphalidae share the exact same perching behavior as that of Hamadryas: Ectima and Panacea [3, 4].

The confirmed host plants of all Hamadryas species are in the genera Dalechampia and Tragia, both in the Euphorbiaceae [4]. The larval body is spiny and has two upwardly elongated spiky horns on the head. All pupae in the genus bear two flattened head horns that show affinities to Ectima [3].

At present, Hamadryas is classified in the BiblidinaeBiblidini, and the most closely related genera are thought to be Panacea, Batesia, and Biblis according to Hill et al. [9] and Ectima according to Jenkins [4]. The goal of this research is to propose a thorough phylogenetic analysis which better represents the evolutionary relationships among Hamadryas species in order to answer three questions: is Hamadryas monophyletic, what is the sister group of Hamadryas, and what characters best define the different species groups of the genus? Also, an identification key to the species of the genus is included in order to make the determination of species easier.

\section{Materials and Methods}

2.1. Species Studied. 223 specimens were analyzed: H. laodamia saurites $n=44, H$. arete $n=1, H$. arinome arinome $n=3, H$. arinome ariensis $n=6, H$. guatemalena guatemalena $n=31, H$. guatemalena elata $n=2, H$. chloe chloe $n=1, H$. epinome $n=5, H$. fornax fornacalia $n=24$, $H$. iphthime iphthime $n=11, H$. iphthime joannae $n=1$, $H$. amphinome amphinome $n=6, H$. amphinome mexicana $n=9, H$. amphinome fumosa $n=1, H$. feronia feronia $n=9$, $H$. feronia farinulenta $n=10, H$. glauconome glauconome $n=14, H$. februa ferentina $n=23, H$. februa februa $n=2$, Ectima erycinoides erycinoides $n=13$, Batesia hypochlora $n=2$, and Panacea procilla lysimache $n=5$. Details of the collecting data of the specimens are in Appendix A.

The species $H$. amphichloe, $H$. julitta, $H$. atlantis, $H$. albicornis, $H$. alicia, $H$. rosandra, and $H$. velutina were analyzed based on photographs of males and females (dorsal and ventral views) and drawings of the male genitalia in Jenkins [4], due to the scarcity of specimens in collections.

2.2. Preparation of Material. Male genitalia were treated with a $10 \%$ potassium hydroxide digestion process. To analyze them a stereomicroscope Nikon model 1064565 and dissection scissors where employed, then the material was stored in glycerol vials in the Insect Museum of the University of Costa Rica.

2.3. Characters and Terminology. The character matrix is composed of 66 characters (all binary), of which 41 were derived from the external morphology and color pattern of the wings, 2 from the color pattern of the body, 2 from the spiral organ morphology inside the fore-wing subcostal vein, and 21 from the male genitalia. Also, three phylogenetic attributes where mapped on the resulting tress: one ethological, one biogeographical, and one physiological.
The terminology of the adult external morphology follows Scoble [10]. Terminology for male genitalia follows Alayo and Hernández [11].

2.4. Phylogenetic Analysis. The first three analyses were done to test if Hamadryas is monophyletic. For that, combinations of the three genera most closely related to Hamadryas were used. The first analysis used Batesia hypochlora C. Felder and R. Felder 1862 as the outgroup with Panacea, Ectima, and Hamadryas as ingroups. The second analysis used Panacea procilla (Hewitson, 1854) as the outgroup with Batesia, Ectima, and Hamadryas as ingroups; in this analysis information concerning the biogeography, palatability, and sound production was mapped onto the phylogeny in order to find useful taxonomic criteria to support the species groups. The third analysis used Ectima erycinoides C. Felder and R. Felder 1867 as the outgroup with Panacea, Batesia, and Hamadryas as ingroups; a fourth analysis was done including as ingroup only what is considered as Hamadryas in Jenkins [4] and with Ectima as the outgroup since this genus has been considered closely related to Hamadryas [3, 4]. For all the analyses I used heuristic searches in WinClada ver. 1.00.08 with a multiple TBR + TBR (mult.max.), unconstrained search strategy with 100 maximum trees to keep hold and without submitting tress, with one single replication $\left(\right.$ Mult $\left.^{*} \mathrm{~N}\right)$ and one starting tree per replication. Also, the same program was used to identify character changes along the branches. Branch support was estimated with Nona ver. 2.8 [12]. All characters were analyzed as nonadditive with Fitch parsimony. The data matrix and character list are in Appendices B and C, respectively.

The identification key to the species was prepared using characters that are easy to distinguish with the naked eye butterfly specimen. The key follows a different logic of characteristics than the one employed by Jenkins [4] and is a new option for the identification of adult Hamadryas.

\section{Results}

The analyses show the phylogenetic relationships obtained between these four closely related genera using Batesia (Figure 1), Panacea (Figure 2), and Ectima (Figure 3) as outgroups. According to Lamas [2] these three genera together with Hamadryas comprise the subtribe Ageronina.

The first analysis used Batesia as an outgroup, two primary trees were obtained (Appendix D) and a majority rules consensus compromise tree was done (Figure 1). The second analysis used Panacea as an outgroup and a single tree was obtained from a heuristic analysis (Figure 2). The third analysis used Ectima as an outgroup, two primary trees were obtained (Appendix E), and a majority rules consensus compromise tree was done (Figure 3 ). The fourth analysis gave a single tree obtained from a heuristic analysis using Ectima as an outgroup of Hamadryas (Figure 4).

Trees in Figures 5, 6, and 7 are the result of using the tree in Figure 2 with biogeography, palatability, and sound production, respectively. The biogeographical inferences were done based on the work of Heppner [13]. 


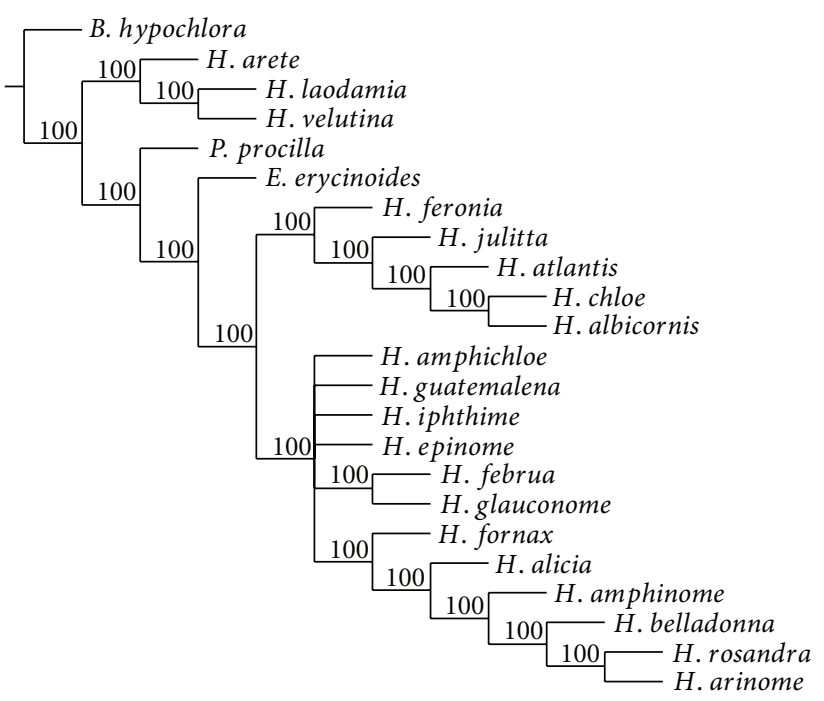

FIGURE 1: Majority rules consensus compromise from two primary trees obtained from a heuristic analysis of 66 characters for 23 species (tree length $=168, \mathrm{CI}=0.39, \mathrm{RI}=0.63$ ). Numbers above tree branches represent consensus compromises. B. hypochlora was used as the outgroup.

The characters found to form the different species groups (Figure 2) are given in Table 1.

Drawings of different structures which are important for the interpretation of the species key (taxonomic characters) are shown in Figures 8 and 9.

\section{Discussion}

Following a single cladistic methodology, four different analyses produced four similar trees, although, some important dissimilarities can be pointed out in order to understand the evolutionary relationships of the groups. The CI (Consistency Index) of all the resulting trees is between 0.39 and 0.50 which is considered appropriate under the scenario presented by $[14,15]$. The use of three other genera together with Hamadryas permits us to test its monophyly [16]. The three analyses where other genera besides Hamadryas are included agree that Hamadryas is polyphyletic, since there is a Hamadryas species group that in all the analyses has a different ancestor than the rest of the Hamadryas species. This group is composed by three species: $H$. laodamia, $H$. arete, and $H$. velutina; it is interesting to note that, these species were treated in the past as a different genus, Peridromia, proposed by $[17,18]$. The analyses from Figure 1 to Figure 3 show the relationships between Hamadryas, Panacea, Ectima, and Batesia. Also, in the fourth analysis (Figure 4), all the Hamadryas were treated with only Ectima as the outgroup, and these three species remained together, which is strong evidence for the monophyly of such a species group.

4.1. Species Group Shared in the Four Analyses. The species groups supported by the strongest evidence based on the results of this paper (because they are identical in the four analyses) are as follows.

4.1.1. H. laodamia, H. velutina, and H. arete (Peridromia Subgenus). The diagnosis of Peridromia was based on characters of the male's forewings, that is, veins $\mathrm{R}_{1}$ and $\mathrm{R}_{2}$ arising on a single stalk and branched almost immediately, a character that is shared with $H$. feronia, $H$. guatemalena, $H$. iphthime, and others [4]. This character is therefore of questionable validity. Instead, the outwardly convex subcostal cell on the male's hind wing, for instance, seem to be a valid synapomorphy of Peridromia.

Consistently, all the trees obtained in this study grouped these three species apart from all others, and when other related genera (Panacea, Batesia, and Ectima) are included, Peridromia is supported as a valid genus apart from Hamadryas. The synapomorphies for this species group are given in Table 1; the presence of a sex patch in males, red spots around the humeral vein on the VHW, and red markings on the ventral area of thorax are considered to be the most valuable taxonomically. Also, in the trees in Figures 5, 6, and 7 the phylogenetic attributes are mapped, and such attributes are also shared on the three species and also are shared with their closest non-Peridromia-taxa: Batesia, these characteristics are probably carried from their hypothetical common ancestor.

Under the scenario where Peridromia should be treated as a genus, three important characteristics might be controversial: the presence of the spiral organ inside the Forewing subcostal vein (even when no audible sound has been demonstrated) [4], the presence of two lateral rammi on the terminal sternite of the abdomen and similarities with Hamadryas in the early stages and host plants [3]. The fact that Peridromia has very distinct characters from all other Hamadryas could instead (and in light of these other characters) be considered evidence for subgenus-level synapomorphies, rather than genus-level synapomorphies; in this scenario the ancestor produced sound but in these species sound (at least that audible to humans) production has been lost even though the organ is still there, as may have happened in species of Satyrinae [19]. This species group probably originated in the "Yungas Montane" biogeographical province in South America and then one species, $H$. laodamia, moved northwards, the subspecies "saurites" through the "Central American woodlands."

4.1.2. $H$. atlantis, $H$. chloe and $H$. albicornis. Another wellsupported species group is the one composed by $H$. chloe and its sister species, $H$. albicornis, plus $H$. atlantis. The affinity of these three species is also supported by recent morphological studies on the spiral organ [20], which includes synapomorphies such as a modification of the spiral organ located in the subcostal vein of the forewings and the lack of the ability of produce human-audible sound. Evidence for the affinities of these three species is not only morphological and ethological, but also, these are the only three species of Hamadryas that do not have an anterior projection in the male's vinculum (Table 1). H. chloe and H. albicornis probably evolved in the South American "Amazonian Rain Forest" from the same 


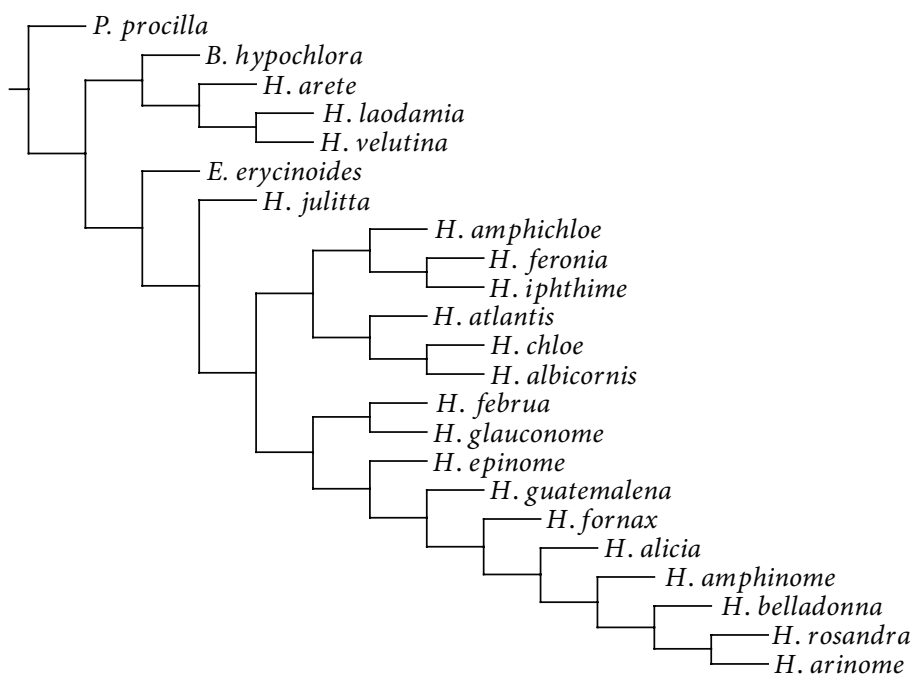

FIGURE 2: Single tree obtained from a heuristic analysis of 66 characters for 23 species (tree length $=161, \mathrm{CI}=0.40$, and RI $=0.65$ ). $P$. procilla was used as the outgroup.

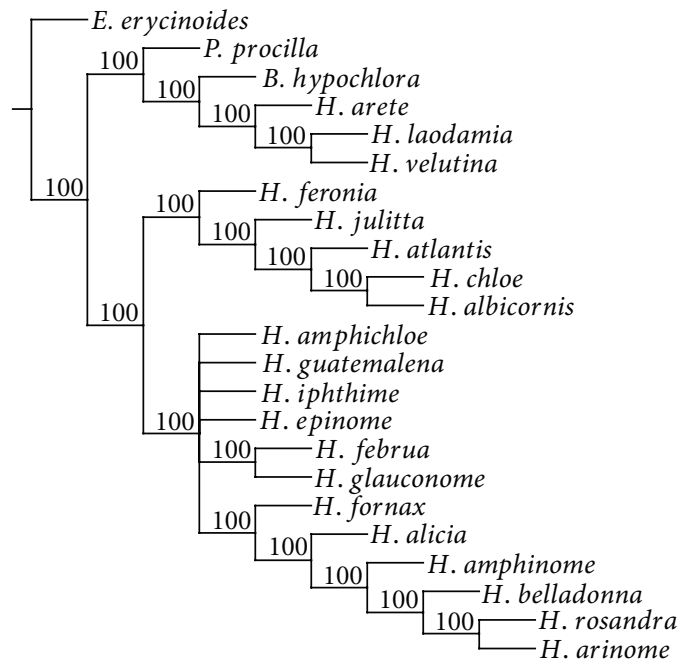

Figure 3: Majority rules consensus tree obtained from two primary trees from a heuristic analysis of 66 characters for 23 species (tree length $=168, \mathrm{CI}=0.39, \mathrm{RI}=0.63)$. Numbers above tree branches represent consensus compromises. E. erycinoides has been used as outgroup.

ancestor from which $H$. atlantis evolved allopatrically in North America, in the "Central American woodlands," and the "Guerreran woodlands" (Figure 5).

\subsection{Species Groups Shared in the Three Analyses of Hamadryas of Figures 1, 2, and 3}

4.2.1. $H$. fornax, $H$. alicia, $H$. rosandra, $H$. belladonna, $H$. amphinome, and $H$. arinome. All these species are distinguished by having orange color of the ventral surface of the hind wings, a character probably lost as an autapomorphy in
H. arinome, but which still retains important male genitalic characters in common with related species (Table 1). Jenkins [4] included in this same species group $H$. feronia, $H$. guatemalena, $H$. iphthime, and $H$. epinome, but the analyses presented here do not support such a grouping and confirm the inclusion of $H$. alicia and $H$. rosandra. This is a typical South American group in which only one species, H. amphinome, probably evolved from the same South American ancestor as $H$. belladonna, $H$. rosandra, and $H$. arinome in the "Amazonian Rain Forest," but its lineage migrated north and colonized Central America, North America and the Northern Caribbean Islands "Cuba" (Figure 5).

4.2.2. H. februa and H. glauconome. These two species are the sister group of the last species group. They evolved from a continental ancestor which was distributed throughout practically all of the Neotropical region. H. glauconome, instead, evolved from the northern population of this hypothetical ancestor in the "Central American woodlands" or the "Guerreran woodlands."

\section{Conclusions}

The close relation between Panacea and Batesia was proposed by Fruhstorfer [21] and then supported by DeVries et al. [22] and Hill et al. [9]. However, in their phylogenetic analysis Hill et al. [9] proposed a clade composed of Panacea and Batesia as the sister group of Hamadryas; in the present analysis (Figure 2). Hamadryas is split into two groups: "Peridromia" as the sister group of Batesia, and the rest of the species of Hamadryas as the sister group of Ectima. Under this scenario, these two clades (Peridromia-Batesia and Hamadryas-Ectima) are sister groups.

The analyses shown in Figures 1 and 2, however, show Ectima to be the genus most closely related to Hamadryas, being their direct outgroup, and leaving Peridromia in 


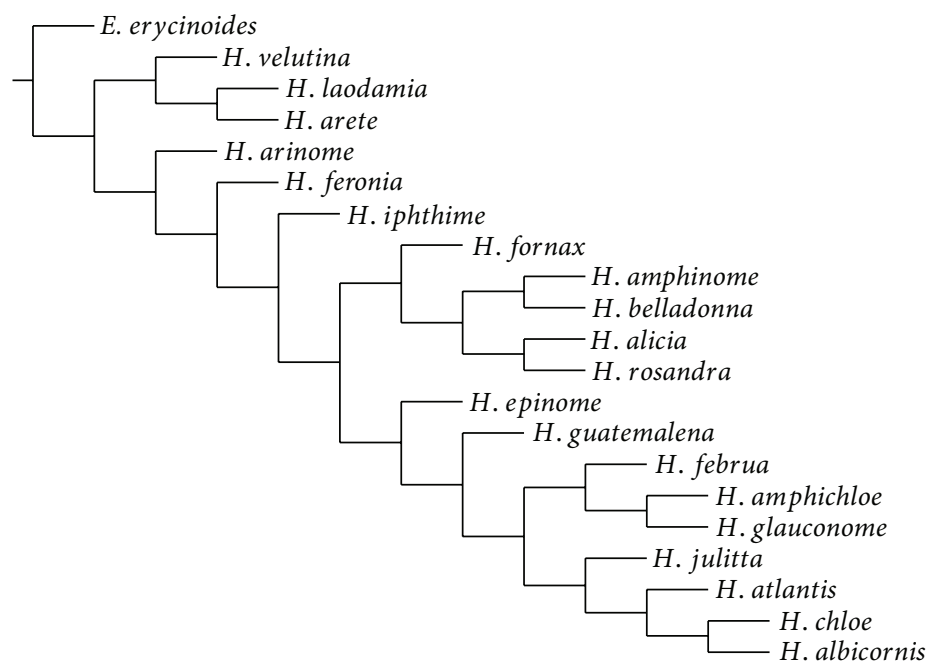

FIGURE 4: Single tree obtained from a heuristic analysis of 66 characters for 21 species (tree length $=126, \mathrm{CI}=0.50$, and RI $=0.69$ ). E. erycinoides has been used as outgroup.

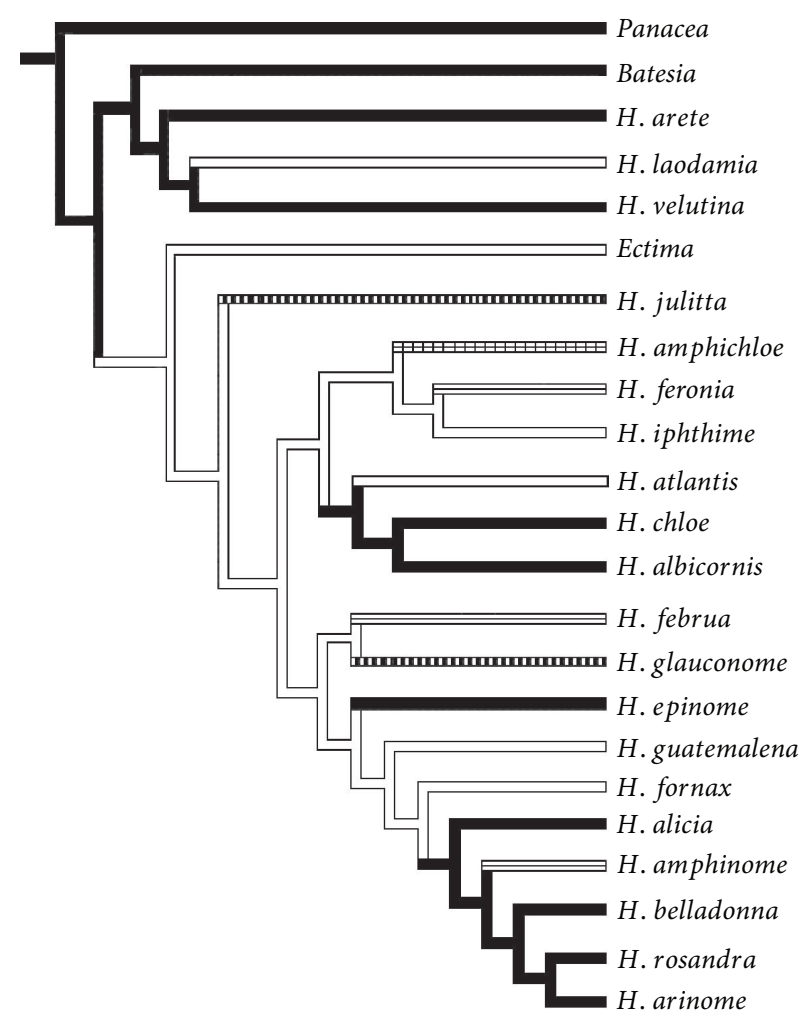

IIII Distributed only in Centranl and North America

- Restricted to South America

Distributed in all the neotropical area except the Caribbean islands

—Distributed in all the neotropical area including the Caribbean islands

Restricted to South America and the Caribbean islands

FIGURE 5: Biogeography of the species mapped on the tree obtained from analyses of the Figure 2. 


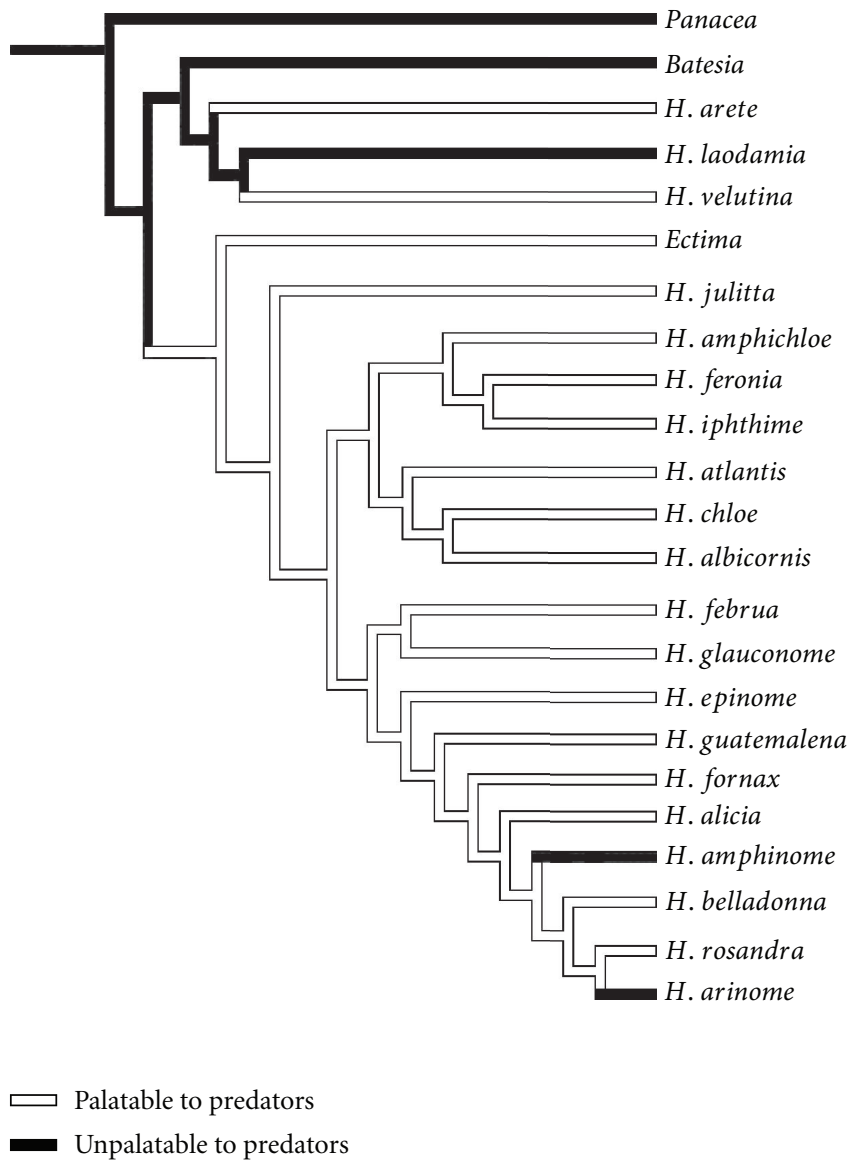

Figure 6: Palatability of the species mapped on the tree obtained from analyses of the Figure 2. The species that lack information of unpalatability are by default considered palatable.

another clade, together with Batesia (Figure 2), or alone (Figure 1). The analysis in Figure 1 seems to be more probable because the early stages and host plants of Batesia might be retained from its ancestor, Panacea, which would have evolved only once, leaving the early stages of Peridromia as a homoplasic regression.

Ectima has been considered to be very closely related to Hamadryas by Jenkins [4, 23] and DeVries [3], which is consistent with the analyses in Figures 1 and 2. The larvae, pupa and behavior of Ectima are very similar to that of Hamadryas but the adults do not possess the spiral organ used in sound production. This evidence suggests that Ectima could be the sister group of Hamadryas. In the analysis of Figure 4 all the current species of Hamadryas are analyzed with Ectima as the outgroup, and again the species group of "Peridromia" kept their independence as the sister group of all the other species.

In all the analyses done in this work, $H$. arete, $H$. laodamia, and $H$. velutina composed a monophyletic group and showed a stronger relation to Panacea and Batesia than to the rest of the Hamadryas species.

Jenkins [4] also supported the close relation between $H$. albicornis and $H$. chloe, but placed them in the $H$. februa Hübner (1819) species group together with $H$. atlantis, $H$. februa, H. amphichloe, H. glauconome, and H. julitta. This species group is recognized by veins $R_{1}$ and $R_{2}$ arising separately from the radial sector before the branching of $\mathrm{R}_{3}$ and is supported in the analysis in Figure 4.

Also, in Figure 4 there is another species group composed by $H$. fornax, $H$. alicia, $H$. rosandra, $H$. amphinome, and $H$. belladonna. Jenkins [4] was uncertain whether $H$. alicia and $H$. rosandra should be placed in this species group, but the new evidence presented here confirms such a group but excludes $H$. arinome, $H$. feronia and $H$. iphtime (which according to Jenkins are included in this group). According to the analysis in Figure 4, similarities such as the dorsal forewings of $H$. arinome and $H$. amphinome may be considered as convergences since they have a different ancestor; $H$. arinome can then be considered as the most basal species of Hamadryas species if Peridromia is excluded from the genus.

More phylogenetic analyses in which early-stage characters are included, in addition to molecular analyses, may provide more evidence as to whether Peridromia should be ranked as a genus in order to make Hamadryas monophyletic.

The tree in Figure 2 is here considered to be the most probable scenario regarding the evolutionary relationships 


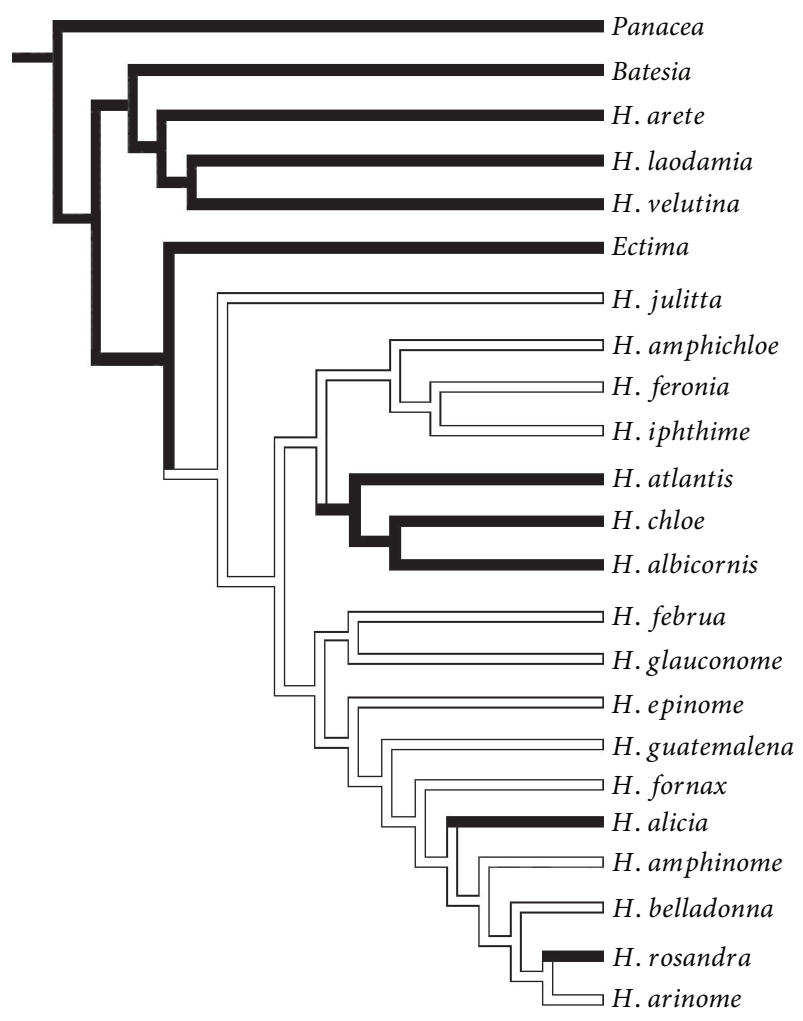

Human audible click noise documented

Human audible click noise not documented

Figure 7: Human audible click noise production mapped on the tree obtained from analyses of the Figure 2.

between Hamadryas and the other three genera included in the analysis. This is because it is the only analysis using the four genera of the subtribe Ageronina in which only one most parsimonious tree was obtained. This scenario suggests the evolution of two different early-stage and host plant lineages: the "Panacea and Batesia-like" which is the root of the tree and the "Ectima-like," which is retained by all species of Hamadryas that evolved from the Ectima-Hamadryas hypothetical ancestor. The "Panacea and Batesia-like" early stages and host plants showed a homoplasic regression in the Peridromia group of Hamadryas since they are more similar to the rest of the "Ectima-like" early stages and host plants [3].

This analysis is the most parsimonious of all the analyses done because it is the one in which the early stages and host plants of Panacea and Batesia evolve only once on a primary most parsimonious tree, with Panacea as the sister genus of Batesia-Peridromia and Ectima-Hamadryas.

The palatability to predators in the genus Hamadryas has been studied by Chai [24, 25] and Srygley and Chai [26]. They provided important statistical evidence of rejection of certain colorations of models by flying predators. According to the present results and observations of DeVries [3], DeVries et al. [22], and Hill et al. [9], it is possible to presume which hypothetical ancestors might be responsible for this strategy and the way it was retained or lost by the different species groups. For instance, it is possible that due to the scarcity and/or lack of studies on species such as $H$. arete and $H$. velutina, no evidence of unpalatability has been documented. Although, it has been proven that the closely related species $H$. laodamia is distasteful, and since these three species evolved from a probable distasteful ancestor it is possible to infer that these two species are also unpalatable to predators. All Peridromia species together with Batesia probably inherited their unpalatability from Panacea, and their sister clade Ectima-Hamadryas lost it as a synapomorphy, although $H$. arinome and $H$. amphinome probably recovered the unpalatability as a homoplasic regression.

The capacity of the studied species to produce human audible clicking noise is also mapped. This ethological attribute is consistent with the unpalatability one. The basal taxa: Panacea, Batesia, and Peridromia lack this ability. It is only in the sister group of Peridromia and Batesia where this character appears. H. julitta seems to be the most plesiomorphic species of Hamadryas which has this ability and it is the sister species of all the rest of Hamadryas. However, the group of $H$. atlantis, $H$. chloe, and $H$. albicornis has lost this ability, and through a different ancestor the same happened to $H$. alicia, and again from a third different ancestor to $H$. rosandra. This convergence makes sense since the last four of these five species share the same dark forest habitat of the "Amazonian Rain Forest" bioprovince. For some reason, in this habitat noise production is not as effective as in others.

The key presented in this paper uses new characters obtained from the careful analysis of the color patterns which helps in the identification of the species; some of the characters are taken from the key presented by Jenkins [4], but are arranged in a different order (Figure 9). All the others are original and the interpretation of the key must be done with Figures 8 and 9. The characters selected do not follow any phylogenetic order.

\section{Key to Species of Hamadryas}

(1) (a) Submarginal ocelli in DHW from $\mathrm{M}_{3}-\mathrm{Cu}_{2}$ circular or tear shaped-2

(b) Submarginal ocelli in DHW from $\mathrm{M}_{3}-\mathrm{Cu}_{2}$ absent-19

(2) (a) Submarginal ocelli in DHW enclosing only one blue spot-3

(b) Submarginal ocelli in DHW enclosing other ocelli or moon-shaped spots of any color- 6

(3) (a) VFW with a white spot or macula in $R_{3}-R_{4}$ anterior of the bifurcation of $\mathrm{R}_{4}-\mathrm{R}_{5}-4$

(b) VFW with no white spot or macula in $\mathrm{R}_{3}-\mathrm{R}_{4}$ just anterior of the bifurcation of $\mathrm{R}_{4}-\mathrm{R}_{5}-H$. arinome

(4) (a) DFW with a white wide median band-5

(b) DFW without the white wide median band- $H$. belladonna $\sigma^{7}$ 
TABLE 1: Characters justifying the grouping of species and genera. WinClada ver. 1.00 .08 was used to map character changes on the three in Figure 2. DFW: dorsal forewings, DHW: dorsal hindwings, VFW: ventral forewings, VHW: ventral hindwings.

Clade 1: (B. hypochlora $+($ H. arete $+(H$. laodamia + H. velutina $))$

$(2: 1)$ Absence of two submarginal ocelli on DHW

(22:1) Absence of submarginal ocelli on DHW

Clade 2: $(H$. arete $+(H$. laodamia $+H$. velutina $))$

$(3: 1)$ Existence of sex patch on DHW

(4:1) Presence of red submarginal spots in VHW

(18:1) Ventral wings with blue iridescent reflectance

(29:1) Existence of red spots around humeral vein in VHW

(33:1) Presence of white in dorsal forewings of females only in the diagonal medial band

(42:1) Red markings on ventral area of thorax

Clade 3: (H. chloe + H. albicornis $)$

(7:1) Forewings with $\mathrm{M}_{3}-\mathrm{Cu}_{2}$ veins extended more than the others

$(8: 1)$ DFW with two red maculae inside discal cell

Clade 4: $(H$. atlantis $+(H$. chloe $+H$. albicornis $))$

(44:0) Spiral organ on forewings sub coastal vein short and thick

(51:1) Vinculum of male genitalia does not have anterior projection

Clade 5: (H. amphichloe + (H. feronia + H. iphthime $))$

(46:1) Distal point of the arm of the gnathos pointing to the uncus

Clade 6: (H. februa + H. glauconome)

(56:1) Uncus overlaps with clasper

Clade 7: (H. epinome + (H. guatemalena $+($ H. Fornax $+($ H. Alicia $+($ H. amphinome $+($ H. belladonna $+($ H. rosandra + H. arinome $))))))$

(35:0) Absence of double concentric ocelli on DHW from $\mathrm{Cu}_{1}$ to $\mathrm{Cu}_{2}$

Clade 8: (H. amphinome $+(H$. belladonna $+(H$. rosandra + H. arinome $))$

(49:1) Point of the arm of the gnathos not acute

(50:1) Arm of the gnathos finishing in a thick triangle

(64:0) Posterior point of the saccus thicker than the rest

Clade 9: (H. belladonna $+(H$. rosandra + H. arinome $)$ )

(39:1) No sexual dimorphism present in the way that discal cell close on the Forewings

Clade 10: $((($ H. atlantis $+($ H. chloe + H. albicornis $))+($ H. amphichloe $+($ H. feronia + H. iphthime $)))+((H$. februa + H. glauconome $)+$ $($ H. epinome $+($ H. guatemalena $+($ H. Fornax $+($ H. Alicia $+($ H. amphinome $+($ H. belladonna $+($ H. rosandra + H. arinome $))))))))$

$(15: 1)$ Existence of color white or gray inside DFW discal cell

(20:1) Hindwings distal border serrated

(21:1) VHW with white marginal spots between veins

(25:1) VHW submarginal ocelli intercalated large ones with smaller ones

(35:1) DHW with two or three concentric ocelli in sub-margins from $\mathrm{Cu}_{1}$ to $\mathrm{Cu}_{2}$

(36:1) Presence of a depression followed by an outward curve on the costal vein at the end of the discal-cell of forewings

(37:1) Females without diagonal wide and regular white band on DFW

(5) (a) DFW in $\mathrm{Cu}_{1}-\mathrm{Cu}_{2}$ with the white macula of the median band enlarged until reaching the point of the bifurcation of $\mathrm{M}_{3}-\mathrm{Cu}_{1}-\mathrm{H}$. belladonna o

(b) DFW in $\mathrm{Cu}_{1}-\mathrm{Cu}_{2}$ with the white macula of the median band finishing two $\mathrm{mm}$ distally from the point of the bifurcation of $\mathrm{M}_{3}-\mathrm{Cu}_{1}-H$. amphinome

(6) (a) VHW with Submarginal ocelli absent in $\mathrm{M}_{2}$ $\mathrm{M}_{3}-\mathrm{H}$. alicia

(b) VHW with Submarginal ocelli or white point present in $\mathrm{M}_{2}-\mathrm{M}_{3}-7$
(7) (a) VHW with four consecutive ocelli of different sizes from $\mathrm{M}_{1}$ to $\mathrm{Cu}_{2}-8$

(b) VHW with four consecutive ocelli of similar size from $\mathrm{M}_{1}$ to $\mathrm{Cu}_{2}-12$

(8) (a) VHW ocelli from $\mathrm{M}_{1}$ to $\mathrm{Cu}_{2}$, the one in $\mathrm{M}_{2}-\mathrm{M}_{3}$ absent or if present then less than a half the diameter of the one in $\mathrm{Cu}_{1}-\mathrm{Cu}_{2}-9$

(b) VHW ocelli from $\mathrm{M}_{1}$ to $\mathrm{Cu}_{2}$, the anterior one large, and the next three small, reduced to white points or absent-11 


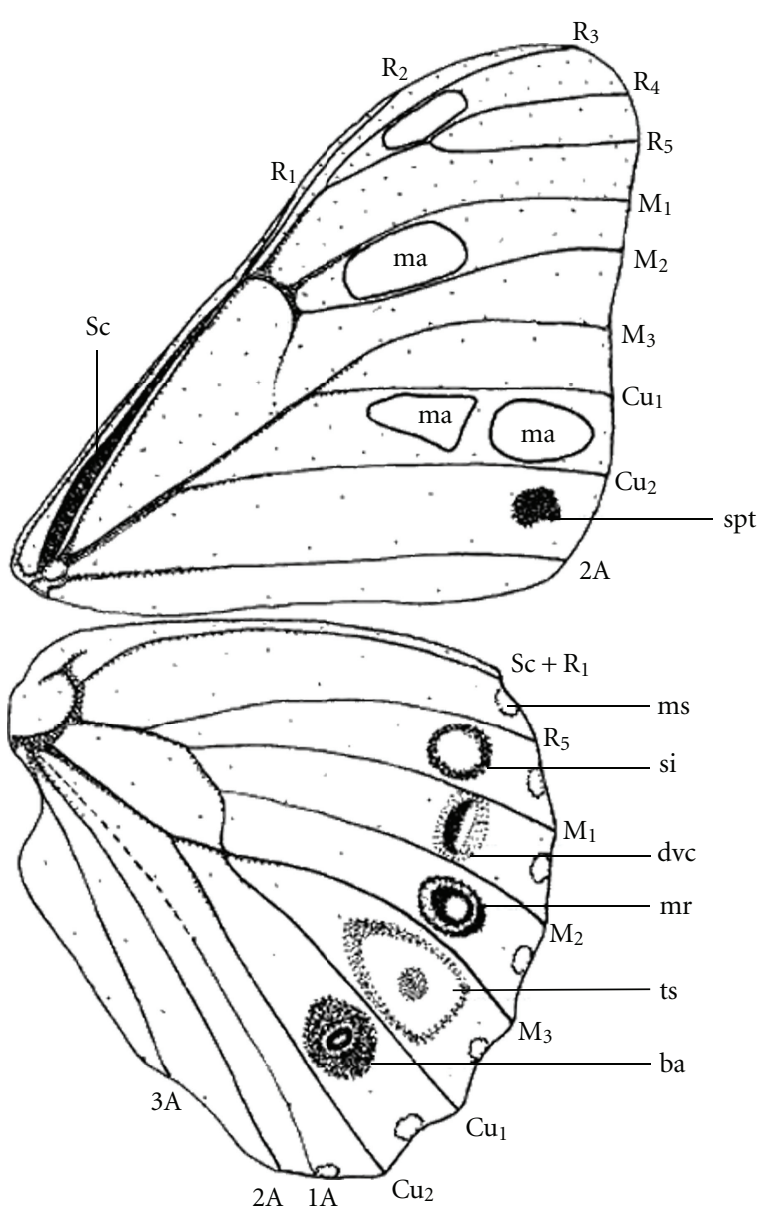

Figure 8: Hypothetical Hamadryas wing as example of different color patterns that are used in the key to the species of Hamadryas: $\mathrm{ma}=$ macula, $\mathrm{spt}=$ spot, $\mathrm{ms}=$ marginal spot, $\mathrm{si}=$ simple ocelli, $\mathrm{dvc}$ $=$ dorsoventrally compressed ocelli, $\mathrm{mr}=$ multi-ring ocelli, $\mathrm{ts}=$ tear shaped ocelli, ba $=$ basic ocelli, $\mathrm{Sc}=$ subcoastal vein .

(9) (a) VHW in $\mathrm{M}_{2}-\mathrm{M}_{3}$ with a small ocelli (sometimes rudimentary) and without a white marginal macula, but if present never as large as the ocelli-10

(b) VHW in $\mathrm{M}_{2}-\mathrm{M}_{3}$ with a small ocelli and a white marginal macula as large or larger than the ocelliH. atlantis

(10) (a) DFW with three rose-red bars or bands on proximal half- - . chloe

(b) DFW without three rose-red bars or bands on proximal half- - . albicornis

(11) (a) DHW ocellus with a black external ring- H. rosandra

(b) DHW ocellus with the external ring any color but black-H. fornax

(12) (a) VHW ocelli composed of a black ring with light center-13 (a)

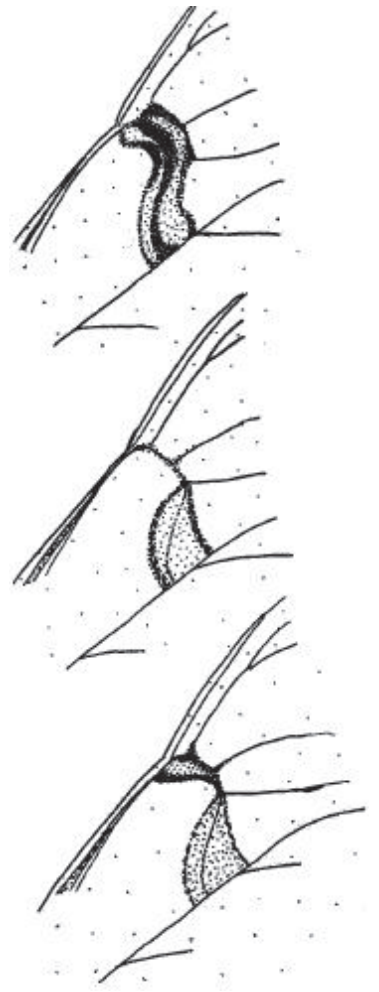

FIGURE 9: Three different patterns in the distal area of the discal cell employed in the Hamadryas identification key, taken from Jenkins [4] with original drawings.

(b) VHW ocelli composed of a complete of incomplete rust-red ring, surrounding a black-crescentshaped moon with white center-16

(13) (a) DFW with a white Submarginal ocellus in $\mathrm{Cu}_{1}$ $\mathrm{Cu}_{2}$ all surrounded by black-14

(b) DFW without any a white Submarginal ocelli in $\mathrm{Cu}_{1}-\mathrm{Cu}_{2}$ all surrounded by black -15

(14) (a) VFW in $\mathrm{R}_{3}-\mathrm{R}_{4}$ with the white Submarginal spot as large as or larger than the marginal spot-H. guatemalena

(b) VFW in $\mathrm{R}_{3}-\mathrm{R}_{4}$ without the white Submarginal spot, but if present then not larger than the marginal spot- $H$. feronia

(15) (a) DHW ocelli form $\mathrm{M}_{3}$ to $\mathrm{Cu}_{2}$ circular or somewhat tear shaped-H. iphtime

(b) DWH ocelli from $\mathrm{M}_{3}$ to $\mathrm{Cu}_{2}$ dorsoventrally compressed-H. epinome

(16) (a) DHW ocelli in $\mathrm{M}_{3}-\mathrm{Cu}_{2}$ dorsoventrally compressed, with a white internal line reaching more than the $70 \%$ of the width between the veins-H. honorina

(b) DHW ocelli in $\mathrm{M}_{3}-\mathrm{Cu}_{2}$ not dorsoventrally compressed, with a white internal line reaching no more than the $50 \%$ of the width between the veins -17 
(17) (a) DFW showing distal cross bar of discal cell completely separated in two clear bands by a thin dark line from level of Radial vein to level of Cubital vein. Figure 9(a)-H. februa

(b) DFW showing distal cross bar of discal cell not completely separated in two clear bands from level of Radial vein to level of Cubital vein (Figures 9(b) and $9(c))-18$

(18) (a) DFW showing distal cross bar in $\mathrm{M}_{2}-\mathrm{M}_{3}$ width, with a constriction at the origin of $\mathrm{M}_{2}$, and becoming width again in $\mathrm{R}_{5}-\mathrm{M}_{1}$ (Figure $\left.9(\mathrm{c})\right)-H$. glauconome

(b) DFW showing distal cross bar in $\mathrm{M}_{2}-\mathrm{M}_{3}$ wide, and finishing at the origin of $\mathrm{M}_{2}$, and not becoming wide again in $\mathrm{R}_{5}-\mathrm{M}_{1}$ (Figure $\left.9(\mathrm{~b})\right)-H$. amphichloe

(19) (a) VHW with red bars or spots in anal cell- $-H$. laodamia

(b) VHW without red bars or spots in anal cell-20

(20) (a) DHW with reddish anterior costal markings- $H$. arete

(b) DWH with no reddish anterior costal markingsH. velutina

(21) (a) DFW in $\mathrm{M}_{2}-\mathrm{M}_{3}$ with only two blue spots- $H$. laodamia

(b) DFW in $\mathrm{M}_{2}-\mathrm{M}_{3}$ with four or five blue spots-22

(22) (a) DHW in Rs-M $\mathrm{M}_{1}$ with three blue spots- $H$. arete

(b) DHW in Rs- $\mathrm{M}_{1}$ with two blue spots- $-H$. velutina

\section{Appendices}

\section{A. 223 Specimens Studied}

Ectima erycinoides erycinoides 707, 60. Costa Rica: Guapiles, Q. Molinete, 400 m. 5-X-2006, col. per. Santa Clara, 400 m. Rec: T. Assmann, col. per. Heredia, Horquetas, 600 m., 8VIII-1993, rec. I. Chacón, MNC. Heredia, Horquetas, 600 m., 11-VIII-1993, rec. I. Chacón, MNC. Limón, Guápiles, 100 m., 30-III-1985, rec. A. Solís, MNC. Puntarenas, Carara, 50 m. 29-V-1990, rec. I. Chacón, MNC. Puntarenas, Golfito, 200 m., 18-II-1982, rec. R. Canet, MNC. Limón, Guápiles, 100 m., 26-III-1978, rec. P. J. DeVries, MNC. Heredia, Horquetas, 600 m., 2-V-1993, rec. I. Chacón, MNC. Heredia, Horquetas, 600 m., 21-VI-1993, rec. I. Chacón, MNC. San José, Mora, El Rodeo, 700 m., 11-VII-1982, rec. R. Canet, MNC. Guanacaste, Volcán Santa Maria, 800 m., 8-VII-1978 rec. P. J. DeVries, MNC. San José, P. N. Braulio Carrillo, 700 m., 6-VII-1989, rec. R. Canet, MNC.

Batesia hypochlora 20'. Peru: Loreto, Iquitos, $100 \mathrm{~m}$. Ene. 2001, col. per. Loreto, Iquitos, 100 m. Ene. 2001, col. per.
Panacea procilla lysimache $40^{7} 1$. . Costa Rica: Guanacaste, La Cruz, Santa Cecilia, 300 m., 18-VI-2009, rec. G. Vega, MNC. Guanacaste, La Cruz, Santa Cecilia, 300 m., 18-VI2009, rec. J. Solano, MNC, Alajuela, Florencia, 6-VI-1995, rec. W. Haber, MNC. Guanacaste, La Cruz, Santa Cecilia, 300 m., 18-VI-2009, rec. J. Solano, MNC. Sin Datos, col. per.

Panacea prola 207. Peru: Manu, Madre de Dios, Feb. 2001, col. per. Manu, Madre de Dios, Feb. 2001, col. per.

Hamadryas laodamia saurites $210^{\top}, 230$. Venezuela: Patanemo, 50 m. Ene. 2006, Rec: E. Lorenzoni col. per. Patanemo, 50 m. Ene. 2006, Rec: E. Lorenzoni col. per. Patanemo, 50 m. Ene. 2006, Rec: E. Lorenzoni col. per. Patanemo, 50 m. Ene. 2006, Rec: E. Lorenzoni col. per. Pijiguaos, 700 m. Oct. 2005, Rec: E. Lorenzoni col. per. Pijiguaos, 700 m. Dic. 2005, Rec: E. Lorenzoni col. per. Costa Rica: Puntarenas, Río Barú, 29-XII-1998, Rec: L. R. Murillo-Hiller, col. per. Puntarenas, Villa Nelly, 500 m., 11-X-1976, rec. P. J. DeVries, MNC. Puntarenas, Carara, 50 m. 1-X-1983, rec. R. Canet, MNC. San José, P. N. Braulio Carrillo, 700 m., 10-IV-1984, rec. I. Chacón, MNC. San José, P. N. Braulio Carrillo, 700 m., 20-V-1984, rec. I. Chacón, MNC. Limón, Guápiles, 100 m., 21-V-1976, rec. P. J. DeVries, MNC. Alajuela, San Miguel, 450 m., 13-XII-1987, rec. R. Canet, MNC. Heredia, La Selva, 50 m., 25-VIII-1979, Rec. P. J. DeVries, MNC. San José, P. N. Braulio Carrillo, 700 m., 1-VI-1984, rec. A. Chacón, MNC. San José, P. N. Braulio Carrillo, 700 m., 10-IV-1984, rec. A. Chacón, MNC. Puntarenas, Carara, 50 m. 1-X-1983, rec. I. Chacón, MNC. Heredia, Horquetas, 600 m., 28-IV1985, rec. I. Chacón, MNC. Heredia, Horquetas, 600 m., 18-III-1993, rec. I. Chacón, MNC. Alajuela, San Carlos, 150 m., 21-VIII-1983, rec. E. Corea, MNC. Puntarenas, Corcovado, 0 m., 7-VI-1986, rec. I. Chacón, MNC. San José, Mora, El Rodeo, 700 m., 11-X-1998, rec. P. Gloor, MNC. Puntarenas, Aguirre, Savegre, 100 m., 20-II-2002, rec. G. Vega, MNC. Puntarenas, Corcovado, 0 m., 17-I1986, rec. R. Canet, MNC. San José, P. N. Braulio Carrillo, 700 m., 24-IV-1984, rec. A. Chacón, MNC. San José, P. N. Braulio Carrillo, 700 m., 15-V-1984, rec. A. Chacón, MNC. San José, P. N. Braulio Carrillo, 700 m., 25-IV-1984, rec. A. Chacón, MNC. Heredia, Horquetas, 600 m., 12-IV1994, rec. J. Solano, MNC. San José, Puriscal, 500 m., 18-I1979, rec. F. Wolg, MNC. Heredia, Magsaysay, 150 m., 15VIII-1981, rec. R. Canet, MNC. San José, P. N. Braulio Carrillo, 700 m., 2410-V-1984, rec. A. Chacón, MNC. San José, P. N. Braulio Carrillo, 700 m., 27-V-1984, rec. A. Chacón, MNC. Heredia, Horquetas, 600 m., 25-V-1993, rec. I. Chacón, MNC. Heredia, Horquetas, 600 m., 22-V-1993, rec. I. Chacón, MNC. Heredia, Horquetas, 600 m., 18-III1993, rec. I. Chacón, MNC. Heredia, Magsaysay, 150 m., 8-VIII-1981, rec. R. Hesterberg, MNC. San José, P. N. Braulio Carrillo, 700 m., 10-IV-1984, rec. A. Chacón, MNC. Puntarenas, Corcovado, 0 m., 30-IV-1985, rec. R. Canet, MNC. San José, P. N. Braulio Carrillo, 700 m., 14-IV-1984, rec. A. Chacón, MNC. Puntarenas, Corcovado, 0 m., 23-VI1986, rec. I. Chacón, MNC. San José, Mora, El Rodeo, 700 m., 25-VII-1997, rec. J. Solano, MNC. San José, Mora, El Rodeo, 
700 m., 30-VIII-1998, rec. P. Gloor, MNC. San José, Dota, 800 m., 22-VII-1998, rec. G. Vega, MNC. San José, Mora, El Rodeo, 700 m., 2-VII-1997, rec. G. Vega, MNC.

Hamadryas arete $10^{7}$. Brazil.

Hamadryas arinome arinome 307. Brazil: Pará. Pará, Obidos, XI-1992, Manuel Ortíz col. per. VENEZUELA: Pijiguaos, 700 m. Feb. 2009, E. Lorenzoni col. per.

Hamadryas arinome ariensis 6op. Costa Rica: Heredia, Horquetas, $600 \mathrm{~m}$., rec. I. Chacón, MNC. Limón, Bordón, 500 m., 27-IV-1995, rec. G. Vega y A. Valerio, MNC. Heredia, Sarapiquí, 50 m., 12-VII-1981, rec. R. Canet, MNC. San José, P. N. Braulio Carrillo, 500 m., 4-VI-1980, rec. P. J. DeVries, MNC. Heredia, Sarapiquí, 50 m., 12-VII-1981, rec. R. Canet, MNC. Limón, Guápiles, 400 m., 28-IV-1988, rec. I. Chacón, MNC.

Hamadryas guatemalena guatemalena 210', 10우. COSTA RICA: Guanacaste, Rincón de la Vieja, 1100 m. 16-IX-1997, Rec: L. R. Murillo-Hiller. Alajuela, La Gúacima, $800 \mathrm{~m}$, 27-IX-2008, Rec: L. R. Murillo-Hiller. Guanacaste, Rincón de la Vieja, 1100 m. 16-IX-1997, Rec: L. R. Murillo-Hiller. Guanacaste, Rincón de la Vieja, 1100 m. 16-IX-1997, Rec: L. R. Murillo-Hiller. Guanacaste, Liberia, $150 \mathrm{~m}$. 6-VII1999, Rec: L. R. Murillo-Hiller. San José, Mora, El Rodeo, 700 m., 31-ago-1994, rec. G. Vega y J. Solano, MNC. Guanacaste, Santa Rosa, 100 m., 15-VI-1978, rec. P. J. DeVries, MNC. Guanacaste, Santa Rosa, 100 m., 1-XII-1976, rec. P. J. DeVries, MNC. Puntarenas, Quepos, 50 m., 27-II1982, rec. R. Hesterberg, MNC. Guanacaste, Palo Verde, 50 m., 30-I-1982, rec. I. Chacón, MNC. Guanacaste, Santa Rosa, 100 m., 3-XII-1979, rec. D.H. Janzen, MNC. Alajuela, Atenas 800 m., 27-XI-1980, rec. R. Canet, MNC. Guanacaste, Santa Rosa, 100 m., I-XII-1976, rec. P. J. DeVries, MNC. Guanacaste, Palo Verde, 50 m., 30-I-1982, rec. I. Chacón, MNC. San José, Dota, 800 m., 22-XII-1998, rec. G. Vega, MNC. Guanacaste, Palo Verde, $50 \mathrm{~m}$., 30-I-1982, rec. I. Chacón, MNC. Guanacaste, Santa Rosa, 100 m., 5-VII-1978, rec. P. J. DeVries, MNC. Guanacaste, Santa Rosa, 100 m., 5VII-1978, rec. P. J. DeVries, MNC. Guanacaste, Palo Verde, 50 m., 30-I-1982, rec. I. Chacón, MNC. Guanacaste, Palo Verde, 50 m., 30-I-1982, rec. I. Chacón, MNC. Puntarenas, Barranca, 200 m., 26-XII-1984, rec. R. Canet, MNC. Puntarenas, Isla San Lucas, 0 m., 14-IX-2005, rec. G. Vega, MNC. Puntarenas, Isla San Lucas, 0 m., 14-IX-2005, rec. G. Vega, MNC. Puntarenas, Barranca, 200 m., 23-II-1982, rec. R. Canet, MNC. Puntarenas, Barranca, 200 m., 21-I-1984, rec. R. Canet, MNC. Guanacaste, Santa Rosa, 100 m., 4-XII1976, rec. P. J. DeVries, MNC. Guanacaste, Palo Verde, 50 m., 30-I-1982, rec. I. Chacón, MNC. Guanacaste, Cerro el Hacha, 18-IX-1987, rec. I. Chacón, MNC. Guanacaste, Palo Verde, 50 m., 30-I-1981, rec. R. Campos, MNC. Guanacaste, Palo Verde, 50 m., 30-I-1981, rec. R. Campos, MNC.
Hamadryas guatemalena elata 20'. Costa Rica: Guanacaste, Liberia, 150 m., 7-VII-1999, Rec: L. R. Murillo-Hiller. Guanacaste, Liberia, 150 m., 6-VII-1999, Rec: L. R. MurilloHiller.

Hamadryas chloe chloe 107. Brazil: Maranhao, Sao Luis, 12VIII-1961, col. per.

Hamadryas epinome 50'. Bolivia: Cochabamba, Limbo, 2000 m. Dic. 2008 col. per. Cochabamba, Limbo, 2000 m. Dic. 2008 col. per. Cochabamba, Limbo, 2000 m. Dic. 2008 col. per. Cochabamba, Limbo, 2000 m. Dic. 2008 col. per. ARGENTINA: Misiones, Dorado, 18-II-1996, M. Ortiz col. per.

Hamadryas fornax fornacalia $110^{7}$, 13ㅇ. Costa Rica: Alajuela, La Guácima, 800 m. VII-2008 col. per. Alajuela, La Guácima, 800 m. IX-2008 col. per. San José, Mora, El Rodeo, 19VI-2009 col. per. San José, Mora, El Rodeo, 19-VI-2009 col. per. Puntarenas, San Vito, 1150 m., 19-IX-1977, rec. G. B. Small, MNC. Alajuela, Atenas 800 m., 17-XII-1977, rec. P. J. DeVries, MNC. Puntarenas, San Vito, 1150 m., 17III-1978, rec. P. J. DeVries, MNC. Puntarenas, Coto Brus, 1500 m., 11-II-1991, rec. A. Solís, MNC. Heredia, San Rafael, 1350 m., 20-VII-1981, rec. R. Canet, MNC. Puntarenas, Coto Brus, 1500 m., 2-II-1991, rec. H. Sparrow, MNC. San José, Mora, El Rodeo, 700 m., 10-VIII-1982, rec. R. Canet, MNC. Puntarenas, Coto Brus, 1500 m., 9-X-1995, rec. I. Chacón, MNC. San José, Acosta, Palmichal, 1400 m., 20-XII-2003, rec. M Alfaro, MNC. Puntarenas, Santamaría de Pittier, 6IX-1984, rec. A. Solís, MNC. San José, Mora, El Rodeo, 700 m., 5-V-1997, rec. G. Vega y J. Solano, MNC. Puntarenas, San Vito, 1150 m., 27-V-1985, rec. R. Canet, MNC. Alajuela, Atenas, 800 m., 17-XII-1977, rec. P. J. DeVries, MNC. San José, Mora, El Rodeo, 700 m., 9-III-1996, rec. G. Vega, MNC. San José, Mora, El Rodeo, 700 m., 2-IX-1996, rec. G. Vega y J. Solano, MNC. San José, Mora, El Rodeo, 700 m., 19VII-1995, rec. G. Vega, MNC. San José, Mora, El Rodeo, 700 m., 2-IX-1997, rec. G. Vega, MNC. San José, Mora, El Rodeo, 700 m., 19-XII-1995, rec. G. Vega, MNC. San José, Mora, El Rodeo, 700 m., 2-X-1995, rec. G. Vega, MNC. San José, Acosta, Palmichal, 1400 m., 22-IX-2003, rec. M Alfaro, MNC.

Hamadryas iphthime iphthime 907, 2o. Costa Rica: Alajuela, La Guácima, 800 m., VII-2008 col. per. Alajuela, La Guácima, 800 m., VII-2008 col. per. San José, Mora, El Rodeo, 700 m., 31-ago-1994, rec. G. Vega y J. Solano, MNC. Puntarenas, Carara, 50 m. 28-May-1983, rec. R. Hesterberg, MNC. San José, Puriscal, 500 m., 18-May-1979, rec. P. J. DeVries, MNC. San José, Mora, El Rodeo, 700 m., 3-ago-1978, rec. P. J. DeVries, MNC. San José, Mora, El Rodeo, 700 m., 7-jul-1988, rec. I. Chacón, MNC. San José, Mora, El Rodeo, 700 m., 11VII-1982, rec. R. Canet, MNC. Puntarenas, Aguirre, Savegre, 100 m., 15-I-2002, rec. G. Vega, MNC. San José, Mora, El Rodeo, 700 m., 19-V-1995, rec. G. Vega y A. Valerio, MNC. 
VENEZUELA: Pijiguaos, 700 m., II 2009 E. Lorenzoni col. per.

Hamadryas iphthime joannae 1․ Venezuela: Caura, Ago2004, E. Lorenzoni col. per.

Hamadryas amphinome amphinome 30', 3o. Venezuela: Pijiguaos, 700 m., Dic. 2005 E. Lorenzoni col. per. Caura, Ago-2004, E. Lorenzoni col. per. Sta. Elena, Vía Paují, 1000 m. Oct. 2002, E. Lorenzoni col. per. BOLIVIA: Cochabamba, Limbo, 2000 m., Ene-2008. Cochabamba, Limbo, 2000 m., Ene-2008. BRASIL: Pará, Obidos, XI-1992, M. Ortíz col. per.

Hamadryas amphinome mexicana 30", 60. Costa Rica: Alajuela, La Guácima, 800 m. Jul. 2008, rec. L. R. Murillo-Hiller. Guanacaste, Rincón de la Vieja, 800 m., 8-VIII-2008, rec. L. R. Murillo-Hiller. Puntarenas, Corcovado, 0 m., 19-XI1976, rec. P. J. DeVries, MNC. Heredia, La Selva, 50 m., 1-VI-1970, Rec. P. J. DeVries, MNC. San José, Mora, El Rodeo, 700 m., 7-X-1984, rec. R. Canet, MNC. Guanacaste, Santa Rosa, 100 m., 6-VII-1979, rec. D. H. Janzen, MNC. San José, Mora, El Rodeo, 700 m., 15-VII-1998, rec. G. Vega, MNC. Alajuela, Grecia, 900 m., 23-XII-1983, rec. R. Campos, MNC. Guanacaste, Santa Rosa, 100 m., 22-VI-1978, rec. P. J. DeVries, MNC.

Hamadryas amphinome fumosa 10'. Colombia: Bojará, Muzo, Ene. 1993. M. Ortiz col. per.

Hamadryas feronia feronia 40 $0^{7}$ 5 9 . Brazil: Maranhao, Sao Luis, 12-VIII-1961, col. per. Sta. Catarina, Bombinhas, 20IX-2003, rec: L. R. Murillo-Hiller. Pará, Obidos, XI-1992, M. Ortíz col. per. VENEZUELA: Hda. Bucarito, Montalban, 700 m., 15-V-1983, rec: L. D. Otero. Urb. Guapazo, Valencia, 500 m., 20-V-1983, rec: L. D. Otero. Urb. Guapazo, Valencia, 500 m., 20-V-1983, rec: L. D. Otero. Pijiguaos, 700 m., feb 2009, E. Lorenzoni col. per. Caura, Km. 20, Mar-2003, E. Lorenzoni col. per.

Hamadryas feronia farinulenta 707, 3o. Costa Rica: San José, Mora, El Rodeo, 800 m., 19-VI-2009, rec: L. R. MurilloHiller. Guanacaste, Liberia, 100 m. 1968, rec: P. Kazan. Alajuela, La Guácima, 2008, rec: L. R. Murillo-Hiller. Alajuela, La Guácima, 2008, rec: L. R. Murillo-Hiller. Alajuela, La Guácima, 2008, rec: L. R. Murillo-Hiller. Alajuela, La Guácima, 2008, rec: L. R. Murillo-Hiller. Guanacaste, Liberia. 100 m., 14-IX-1980, rec: Y. Chavarri, col: MIUCR.

Puntarenas, Corcovado, 0 m., 28-VI-1986, rec. I. Chacón, MNC. Puntarenas, Aguirre, Savegre, 100 m., 20-II-2002, rec. G. Vega, MNC. Puntarenas, Corcovado, 0 m., 27-I-1980, rec. R. Canet, MNC.

Hamadryas glauconome glauconome 120', 2o. Costa Rica: Guanacaste, Liberia, 100 m. rec: T. Assmann. Guanacaste,
Liberia, 100 m., 13-V-1980, col. MIUCR. Puntarenas, Barranca, 200 m., 27-II-1982, rec. R. Canet, MNC. Puntarenas, Barranca, 200 m., 5-VII-1981, rec. R. Canet, MNC. Guanacaste, Palo Verde, 50 m., 30-I-1982, rec. I. Chacón, MNC. Guanacaste, Río Corobicí, 90 m., 7-V-1976, rec. P. J. DeVries, MNC. San José, Tibás, 1200 m., 12-XII-1977, rec. P. J. DeVries, MNC. Guanacaste, Santa Rosa, 100 m., 27-VI-1977, rec. P. J. DeVries, MNC. Guanacaste, Palo Verde, 50 m., 30-I1982, rec. I. Chacón, MNC. Guanacaste, Santa Rosa, 100 m., 12-VI-1977, rec. P. J. DeVries, MNC. Guanacaste, Palo Verde, 50 m., 30-I-1982, rec. I. Chacón, MNC. Guanacaste, Santa Rosa, 100 m., 26-VI-1978, rec. P. J. DeVries, MNC. Heredia, San Rafael, 1250 m., 25-VIII-1981, rec. R. Canet, MNC.

Hamadryas februa ferentina 110 $\sigma^{\prime}, 11$. . Costa Rica: San José, Mora, El Rodeo, 1995, rec: L. R. Murillo-Hiller. San José, Mora, El Rodeo, 1995, rec: L. R. Murillo-Hiller. Alajuela, La Guácima, 800 m., 13-IX-2008, rec: L. R. Murillo-Hiller. Alajuela, La Guácima, 800 m., 13-IX-2008, rec: L. R. MurilloHiller. Guanacaste, Rincón de la Vieja, 800 m. 8-VIII-2008, rec: L. R. Murillo-Hiller. Alajuela centro, 800 m., 19-XI1986, rec: A. Ureña. Guanacaste, Rincón de la Vieja, 800 m. 16-VII-1997, rec: L. R. Murillo-Hiller. San José, Escazú, 1300 m., 3-Ago-1978 L. R. Murillo-Hiller col. per. Alajuela, La Guácima, 800 m., 10-VIII-2008, rec: L. R. Murillo-Hiller. Puntarenas, Sta. Teresa, 0 m., 21-XIII-2008, L. R. MurilloHiller col. per. Alajuela, La Guácima, 800 m., Jul-2008, rec: L. R. Murillo-Hiller. Alajuela, La Guácima, 800 m., Jul-2008, rec: L. R. Murillo-Hiller. BRASIL: Rio Grande do Sul, Porto Alegre, 22-IV-1940. Pará, Obidos, XI-1992, M. Ortíz col. per. VENEZUELA: Pijiguaos, 400 m., 2005, E. Lorenzoni col. per. Urb. Guapazo, Valencia, 500 m., 28-V-1983, rec: E. Carabobo. COLOMBIA: Boyacá, Muzo, I-1993, M. Ortiz col. per. Guanacaste, Santa Rosa, 100 m., 5-VII-1976, rec. P. J. DeVries, MNC. Puntarenas, Barranca, 200 m., 27-II-1982, rec. R. Canet, MNC. Guanacaste, Palo Verde, 50 m., 30-I1982, rec. I. Chacón, MNC. Guanacaste, Santa Rosa, 100 m., 1-XII-1976, rec. P. J. DeVries, MNC.

Hamadryas februa februa 10", 1ㅇ. Brazil: Rio Grande do Sul, Porto Alegre, X-2003, rec: L. R. Murillo-Hiller. BOLIVIA: Cochabamba, Limbo, Ene-2008, L. R. Murillo-Hiller col per.

\section{B. Data Matrix for Philogenetic Analyses}

See Table 2 .

\section{Character List Used to Obtain Data for Phylogenetic Analysis, Terminology Follows Jenkins [4]}

\section{Wing Character}

(1) Predominant dorsal wings color any except black (0), black (1). 
TABLE 2

\begin{tabular}{llllllll}
\hline E. erycinoides & 0000000000 & 0000001000 & 0000000001 & 0000000100 & $100-000100$ & 0000000000 & 000010 \\
B. hypochlora & 1100100001 & $10010-0010$ & 0101000000 & 1001000001 & $100-00---0$ & 0000111001 & $11-001$ \\
P. procilla & 1000000010 & 1101001010 & 0000010001 & 1000100001 & $101-001000$ & 0000000101 & 111001 \\
H. februa & 0000110001 & 1011111001 & 1001101101 & 0000111000 & 0001100100 & 0010111011 & 110010 \\
H. amphichloe & 0000110001 & 1011111001 & 1001101101 & 0000111000 & 0001111100 & 0000101011 & 110101 \\
H. glauconome & 0000110001 & 1011111001 & 1000101101 & 0000111000 & 0001111110 & 0010111011 & 110110 \\
H. julitta & 0000100001 & 1011111001 & 1000101101 & 0000111000 & 0001101011 & 0010100011 & 110000 \\
H. atlantis & 0000100001 & 1111111001 & 1001101101 & 0000111000 & 0000100011 & $1--1101001$ & 010101 \\
H. chloe & 0000001111 & 1011111001 & 1001101101 & 0000111000 & 0000111000 & $1--1001101$ & 110111 \\
H. albicornis & 0000001111 & 1011111001 & 1001101101 & 0000111000 & 0000101100 & $1--1001101$ & 110111 \\
H. feronia & 0000100001 & 1011111001 & 1001101101 & 0000011000 & 0001111111 & 0011100011 & 110101 \\
H. guatemalena & 0000100001 & 1011111001 & 1001101101 & 0000011000 & 0001100100 & 0010101011 & 110110 \\
H. iphthime & 0000100001 & 1011111001 & 1001101101 & 0000011000 & 0001111100 & 0010101011 & 110001 \\
H. epinome & 0000100001 & 1011111001 & 1001101101 & 0000011000 & 0001100101 & 0010101011 & 110111 \\
H. fornax & 0000100001 & 1011111001 & 1001111101 & 0000011010 & 0011100100 & 0010101011 & 110110 \\
H. alicia & 0000100001 & 1011111001 & 1011111101 & 0001011001 & 0011100000 & 0001100011 & 110100 \\
H. rosandra & 0000100001 & 1011111001 & 1000111101 & 0001011011 & 0011100111 & 0100101100 & 110001 \\
H. amphinome & 0000100000 & 0011111001 & 1011111101 & 0000011001 & 0011100011 & 0010101011 & 110000 \\
H. belladonna & 0000100000 & 1111111001 & 101111101 & 0001011011 & 0011100111 & 0010101011 & 110010 \\
H. arinome & 0001100000 & 0011111001 & 1011110001 & 1101011010 & 0001100111 & 0010101000 & 000000 \\
H. laodamia & 1111100000 & 1110001110 & 0101000010 & 1111000111 & 0101101100 & 0010001000 & 000010 \\
H. arete & 1111100000 & 1100001110 & 0101000010 & 1111000111 & 0101101100 & 0110001000 & 110001 \\
H. velutina & 1111100000 & 1100001110 & 0101000010 & 1111000101 & 0101101100 & 0110000000 & 110010 \\
\hline
\end{tabular}

(2) Presence of at least two submarginal ocelli on DHW (0), absence of ocelli (1).

(3) Absence of sex patch on DHW (0), existence of such structure (1).

(4) Absence of red submarginal spots on VHW (0), presence of such pattern (1).

(5) Spots or maculae inside the discal cell of VHW (0), devoid of such a pattern (1).

(6) DHW submarginal ocelli without red-rust scales (0), presence of such scales (1).

(7) Hind wings veins from $\mathrm{M}_{3}-\mathrm{Cu}_{2}$ not longer than the rest (0), such veins longer than the rest (1).

(8) DFW without two red maculae inside the discal cell $(0)$, with such a pattern (1).

(9) VHW without red maculae inside the discal cell (0), with such a pattern (1).

(10) Female with a wide diagonal white band on DFW (0), devoid such a pattern (1).

(11) Male with a wide diagonal white band on DFW (0), devoid such a pattern (1).
(12) Wings color no sexual dimorphic (0), wings color sexually dimorphic (1).

(13) On males Forewings the discal cell closes right on the bifurcation of $\mathrm{M}_{3}-\mathrm{Cu}_{1}(0)$, the discal cell close anteriorly of such bifurcation (1).

(14) Forewing apex closer to the body than distal border (0), Forewing apex more distant to the body than distal border (1).

(15) Absence of white or gray inside the discal cell of DFW (0), presence of such a pattern (1).

(16) Females DFW with turnus macula not split in two (0), such macula completely divided in two (1).

(17) DFW discal cell solid color or with dots (0), with lines or maculae (1).

(18) Ventral wings without iridescent reflectance (0), with iridescent reflectance (1).

(19) Females DFW with a white submarginal macula from $R_{5}$ to $M_{1}(0)$, devoid of such a pattern (1).

(20) Hing wings distal border not serrated (0), serrated (1). 


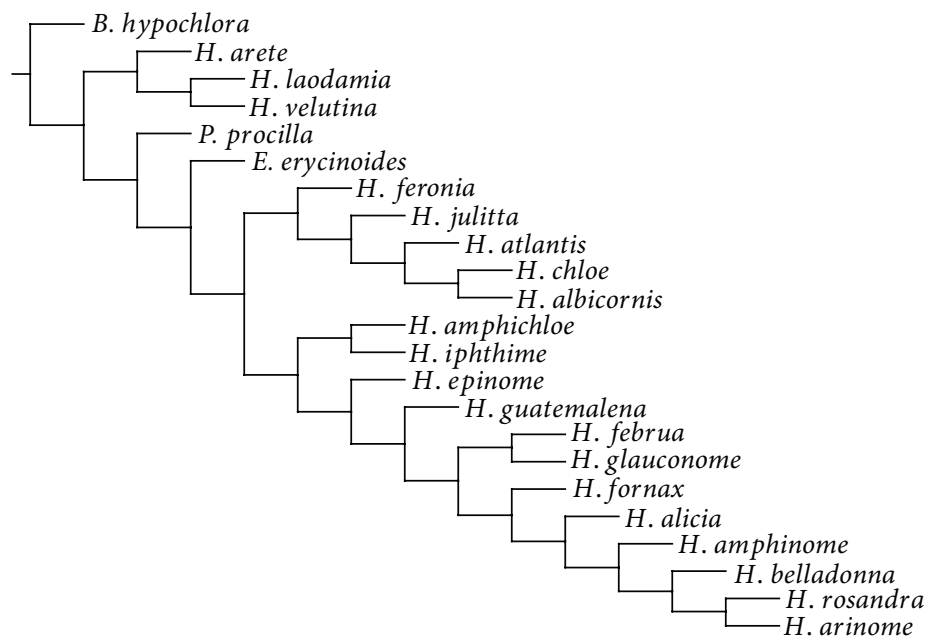

FIgURE 10

(21) Without a white spot on distal border of the VHW between each vein (0), with such a spot (1).

(22) Presence of submarginal ocelli in DHW (0), devoid of such a pattern (1).

(23) Absence of tear shaped submarginal ocelli on DHW (0), presence of such a pattern (1).

(24) Presence of dorsoventrally compressed submarginal ocelli on DHW (0), absence of such a pattern (1).

(25) VHW submarginal ocelli all similar size (0), presenting small ones between big ones (1).

(26) VHW not presenting proximal half orange-red color (0), presenting orange-red color (1).

(27) Absence of a white marginal macula on VFW from $\mathrm{m}_{2}$ to $\mathrm{m}_{3}$ and another from $\mathrm{cu}_{1}$ to $\mathrm{cu}_{2}(0)$, presence of both macula (1).

(28) Absence of a white submarginal macula form $r_{3}$ to $r_{4}$ on DFW (0), presence of such a macula (1).

(29) Absence of red spots at the side of the humeral vein on VHW (0), presence of such spots (1).

(30) Absence of a row of submarginal ocelli on DHW (0), presence of that pattern (1).

(31) Females presenting a submarginal white macula on VFW from $r_{5}$ to $m_{1}(0)$, devoid of such a pattern (1).

(32) Absence of a proximal red spot on VHW from $\mathrm{Sc}+\mathrm{r}_{1}$ to $r_{5}(0)$, presence of such a spot (1).

(33) Females present white coloration in other parts of the DFW besides the white diagonal band (0), devoid of such a pattern (1).

(34) Presence of a submarginal ocelli on DHW from $\mathrm{m}_{2}$ $\mathrm{Cu}_{2}(0)$, devoid of such a pattern (1).

(35) Absence of a double concentric ocelli on DHW from $\mathrm{Cu}_{1}$ to $\mathrm{Cu}_{2}(0)$, presence of such ocelli (1).
(36) Absence of a coastal depression at the distal end of the discal cell followed by a bump on the Forewings (0), presence of such a depression (1).

(37) Females DFW with the diagonal white band not fragmented (0), diagonal white band fragmented in many parts or absent (1).

(38) Forewing with distal border straight (0), distal border convex (1) (Modification of character no. 1 of [9]).

(39) No sexual dimorphism present in the way that discal cell close on the Forewings (0), sexual dimorphism present in such a character (1).

(40) Cryptic coloration on VHW (0), aposematic (1).

Body

(41) Rammi presented (0), rammi absent (1).

(42) Ventral thorax sides without red markings (0), with red markings (1).

(43) Ventral thorax not completely orange (0), completely orange (1) (Modification of character no. 24 of [9]). Spiral Organ

(44) Spiral organ on Forewings short and thick (0), long and thin (1) [20].

(45) Absence of the spiral organ (0), presence of the spiral organ (1).

\section{Male Genitalia Characters}

(46) Distal point of the arm of the gnathos do not point to the distal point of the uncus (0), distal point of the arm of the gnathos pointing to the uncus (1).

(47) Arm of the gnathos as thick or less than the uncus (0), thicker than the uncus (1).

(48) Arm of the gnathos with elbow of more than $90^{\circ}(0)$, less than $90^{\circ}(1)$. 


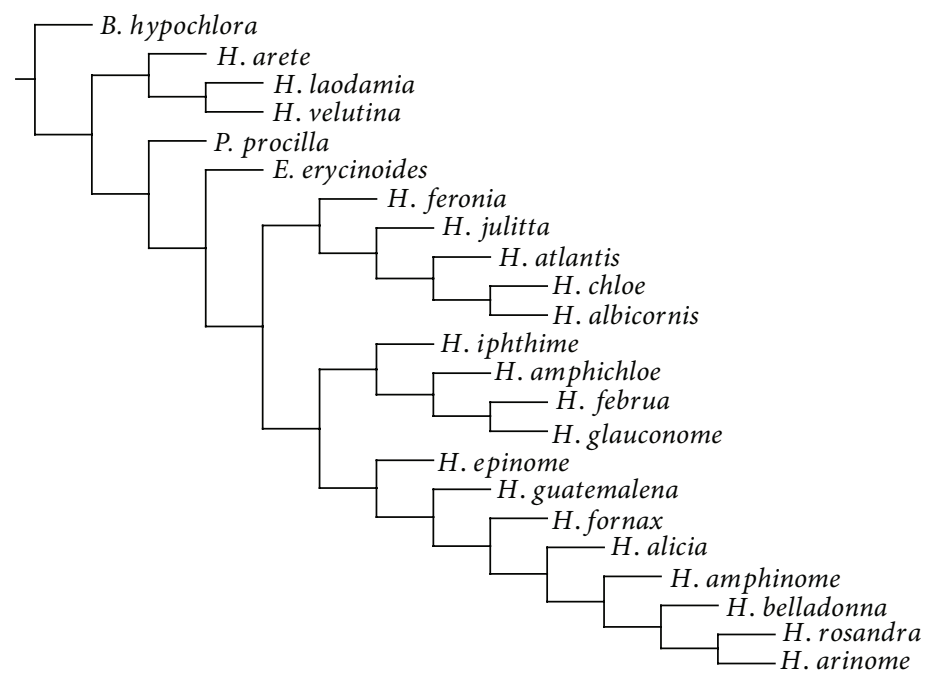

Figure 11

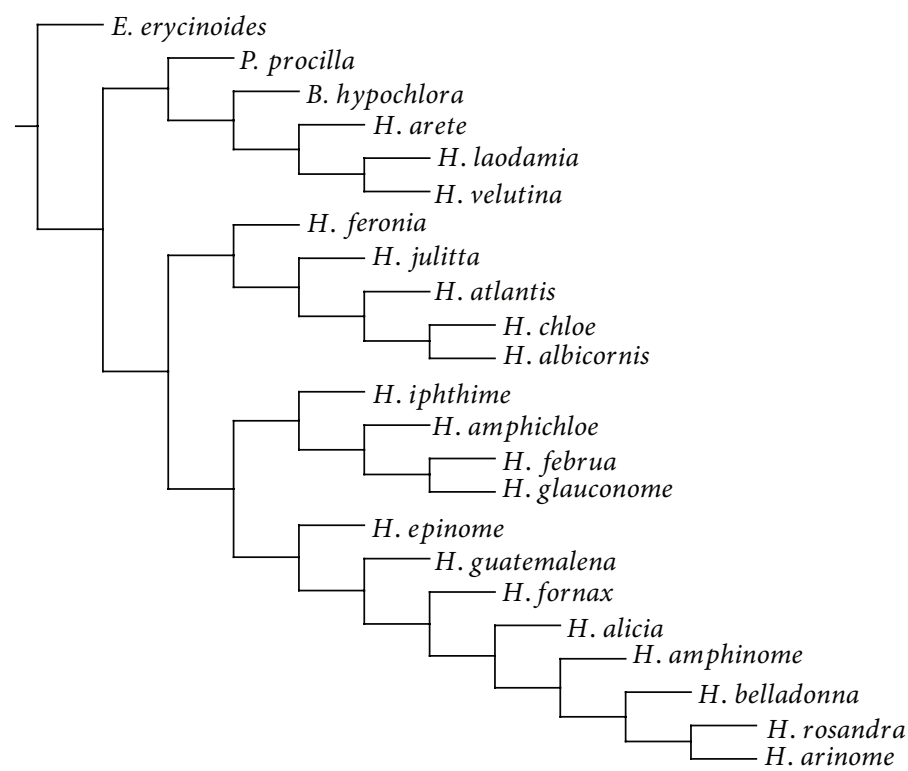

Figure 12

(49) Point of the arm of the gnathos acute (0), devoid of such a pattern (1).

(50) Arm of the gnathos finishing in any shape except a thick triangle (0), finishing in a thick triangle (1).

(51) Vinculum with an anterior projection (0), devoid of such a pattern (1).

(52) Anterior projection of vinculum closer to the saccus than to the tegumen (0), closer to the tegumen (1).

(53) Anterior projection of vinculum round pointing (0), acute (1).

(54) Uncus without setae dorsally (0), with long setae (1) ([9], character no. 35).
(55) Uncus same long or longer than clasper (0), shorter than clasper (1).

(56) Uncus do not overlaps with clasper (0), overlapping (1).

(57) Medial part of the uncus as thick as the posterior part (0), less thick (1).

(58) Uncus without dorsal depression (0), with depression (1).

(59) Valva without dorsal callus (0), with dorsal callus (1).

(60) Valva twice thicker than the saccus (0), valva three times thicker than the saccus (1). 


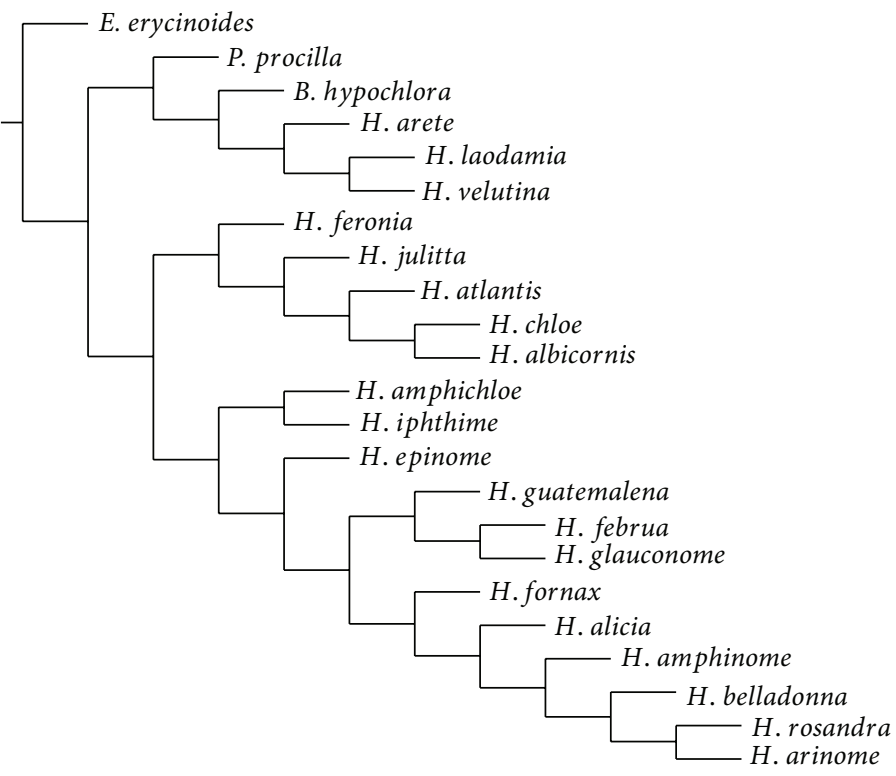

FIgURE 13

(61) Valva length less than a half of the length of the saccus (0), valva length longer than a half of the saccus (1).

(62) Saccus longer than the rest of the genitalia (0), same or shorter than the rest of the genitalia (1).

(63) Saccus as thick or less than the arm of the gnathos (0), saccus thicker (1).

(64) Posterior point of the saccus thicker than the rest (0), devoid of such a pattern (1).

(65) In lateral view, anterior portion of tegumen extremelly proiected (0), devoid of such a pattern (1) ([9], character no. 29).

(66) Anterior portion of tegument less or same long than the projection of the vinculum (0), longer than the projection of the vinculum (1).

\section{The Two Most Parsimonious Primary Trees Obtained from the Phylogenetic Analysis of Hamadryas, Panacea and Ectima Using Batesia as Outgroup. $\mathrm{L}: \mathrm{161}, \mathrm{CI}: 0.40$ and $\mathrm{RI}: 0.65$}

See Figures 10 and 11.

\section{E. The Two Most Parsimonious Primary Trees Obtained from the Phylogenetic Analysis of Hamadryas, Panacea and Batesia Using Ectima as Outgroup. $\mathrm{L}: \mathrm{161}, \mathrm{CI}: 0.40$ and $\mathrm{RI}: 0.65$}

See Figures 12 and 13.

\section{Acknowledgments}

The author thanks James Coronado for important discussion of the paper, J. Monge-Nájera and Paul Hanson for providing helpful literature and also for providing critical comments and a review of the paper, Enrique Lorenzoni and Manuel Ortiz for providing important specimens from their collections, Axel Retana for sharing methodology comments, and German Vega for allowing access to the Museo Nacional de Costa Rica collection.

\section{References}

[1] E. Mayr, "Evolutionary taxonomy," in Evolución y Filogenia de Arthropoda, A. Melic, J. J. DeHaro, M. Méndez, and I. Ribera, Eds., vol. 26, Boletín de la S.E.A., 1999.

[2] G. Lamas, "Biblidinae," in Atlas of the Neotropical Lepidoptera, G. Lamas, Ed., vol. 5, part 4, pp. 224-234, HesperioideaPapilionoidea. Scientific, Florida, Fla, USA, 2004

[3] P. J. DeVries, The Butterflies of Costa Rica and Their Natural History: Papilionidae, Pieridae, Nymphalidae, Princeton University Press, New Jersey, NJ, USA, 1987.

[4] D. W. Jenkins, "Neotropical Nymphalidae I. Revision of Hamadryas," Bulletin of the Allyn Museum, vol. 81, pp. 1-146, 1983.

[5] S. L. Swihart, "Hearing in butterflies (Nymphalidae: Heliconius, Ageronia)," Journal of Insect Physiology, vol. 13, no. 3, pp. 469-476, 1967.

[6] J. Monge-Nájera, "Clicking butterflies, Hamadryas, of Panama: their biology and classification (Lepidoptera, Nymphalidae)," in Insects of Panama and Mesoamerica: Selected Studies, D. Quintero and A. Aiello, Eds., pp. 567-572, Oxford University, Oxford, UK, 1992.

[7] J. Monge-Nájera, F. Hernández, M. I. González, J. Soley, J. Araya, and S. Zolla, "Spatial distribution, territoriality and sound production by tropical cryptic butterflies (Hamadryas, Lepidoptera: Nymphalidae): implications for the "industrial 
melanism" debate," Revista de Biologia Tropical, vol. 46, no. 2, pp. 297-330, 1998.

[8] J. E. Yack, L. D. Otero, J. W. Dawson, A. Surlykke, and J. H. Fullards, "Sound production and hearing in the blue cracker butterfly Hamadryas feronia (Lepidoptera, Nymphalidae) from Venezuela," Journal of Experimental Biology, vol. 203, part 24, pp. 3689-3702, 2000.

[9] R. I. Hill, C. M. Penz, and P. J. Devries, "Phylogenetic analysis and review of Panacea and Batesia butterflies (Nymphalidae)," Journal of the Lepidopterists' Society, vol. 56, no. 4, pp. 199-215, 2002.

[10] M. Scoble, The Lepidoptera: Form, Function and Diversity, Oxford University Press, New York, NY, USA, 1992.

[11] P. Alayo and L. R. Hernández, Atlas de Las Mariposas Diurnas de Cuba, Editorial Científico-Técnica, La Habana, Cuba, 1981.

[12] P. A. Goloboff, "A bastard son of Pee-Wee," Version 2.0. For Windows, 1993.

[13] J. B. Heppner, Faunal Regions and the Diversity of Lepidoptera. Tropical Lepidoptera, chapter 1, 1991.

[14] E. J. López Caballero and G. Pérez Suárez, "Métodos de análisis en la reconstrucción filogenética," Boletín de la SEA, vol. 26, pp. 45-56, 1999.

[15] E. J. López Caballero and G. Pérez Suárez, "Métodos de análisis en la reconstrucción filogenética," Boletín de la SEA, vol. 26, pp. 45-56, 1999.

[16] M. A. Arnedo, "La reconstrucción filogenética basada en parsimonia," Boletín de la SEA, no. 26, pp. 57-84, 1999.

[17] J. T. Lacordaire, "Notice sur les habitudes des Lepidopteres Rhopaloceres (Diurnes) de la Guyana francaise," Annales de la Société Entomologique de France, vol. 2, pp. 379-397, 1833.

[18] J. T. Lacordaire, "Notice sur les habitudes des Lepidopteres Rhopaloceres (Diurnes) de la Guyana francaise," Annales de la Société Entomologique de France, vol. 2, pp. 379-397, 1833.

[19] L. R. Murillo-Hiller, "A noise producing butterfly, Iphthimoides castrensis (Nymphalidae, satyrinae) from South Brazil," Journal of the Lepidopterists' Society, vol. 60, no. 1, pp. 61-63, 2006.

[20] L. R. Murillo-Hiller, "The spiral organ responsible for producing sound signals, an essential taxonomic character in the phylogenetic analysis of the genus Hamadryas (Nymphalidae: Biblidinae): the case of Hamadryas chloe chloe (Stoll) [1787] from South America," ISRN Zoology, vol. 2011, Article ID 170829, 3 pages, 2011.

[21] H. Fruhstorfer, "Batesia," in The Macrolepidoptera of the World, A. Seitz, Ed., vol. 5, p. 537, 1916.

[22] P. J. DeVries, C. M. Penz, and T. R. Walla, "The biology of Batesia hypochlora in a Ecuadorian rainforest (Lepidoptera: Nymphalidae)," Tropical Lepidoptera, vol. 10, no. 2, pp. 43-46, 1999.

[23] D. W. Jenkins, "Neotropical nymphalidae IV: revision of Ectima," Bulletin of the Allyn Museum, vol. 95, pp. 1-29, 1985.

[24] P. Chai, "Field observations and feeding experiments on the responses of rufous-tailed jacamars (Galbula ruficauda) to free-flying butterflies in a tropical rainforest," Biological Journal of the Linnean Society, vol. 29, no. 3, pp. 161-189, 1986.

[25] P. Chai, "Wing coloration of free-flying neotropical butterflies as a signal learned by a specialized avian predator," Biotropica, vol. 20, no. 1, pp. 20-30, 1988.

[26] R. Srygley and P. Chai, "Predation and the elevation of thoracic temperature in brightly colored Neotropical butterflies," American Naturalist, vol. 135, no. 6, pp. 766-787, 1990. 

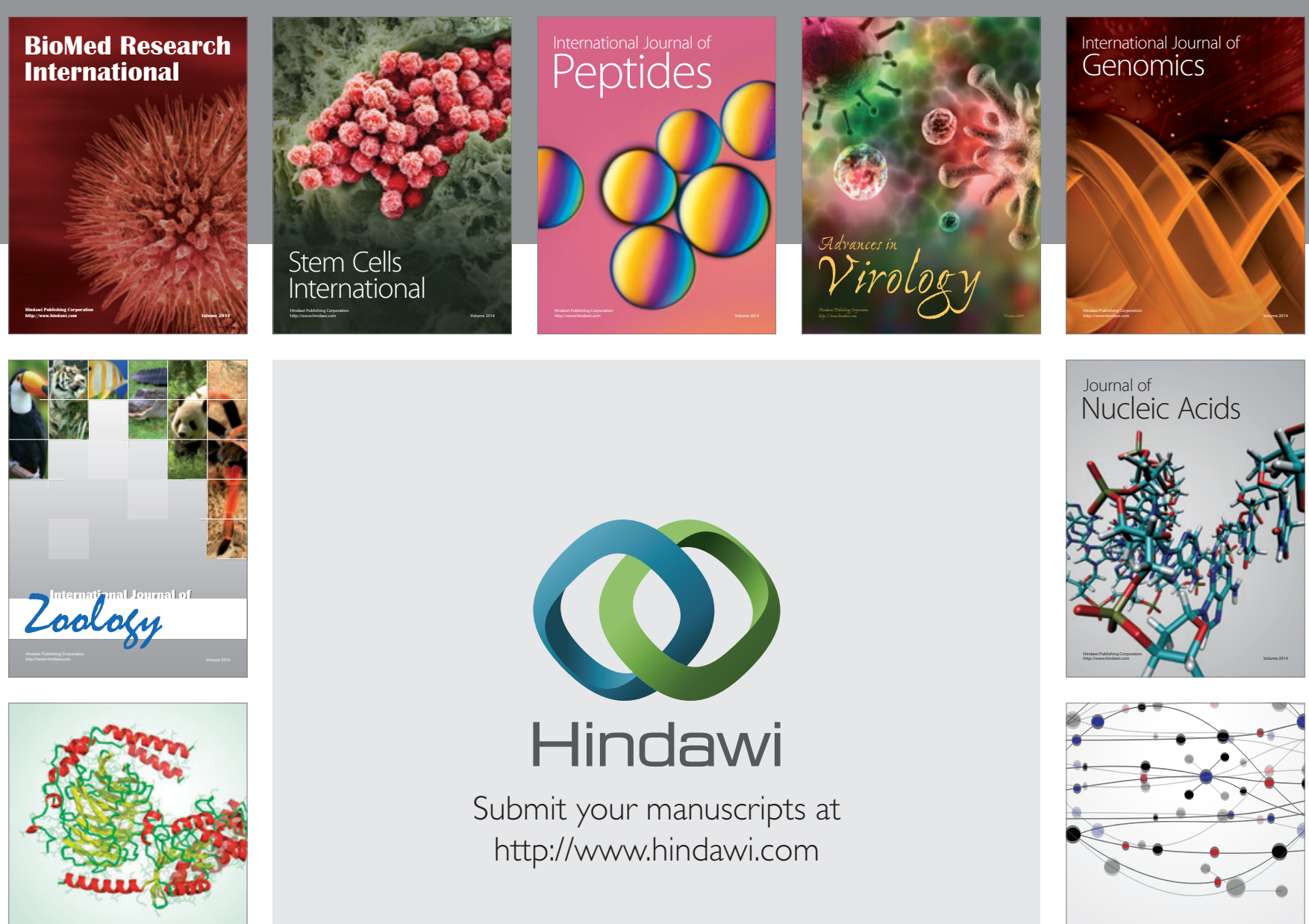

Submit your manuscripts at

http://www.hindawi.com

Signal ${ }^{\text {Jumal }}$ Transduction
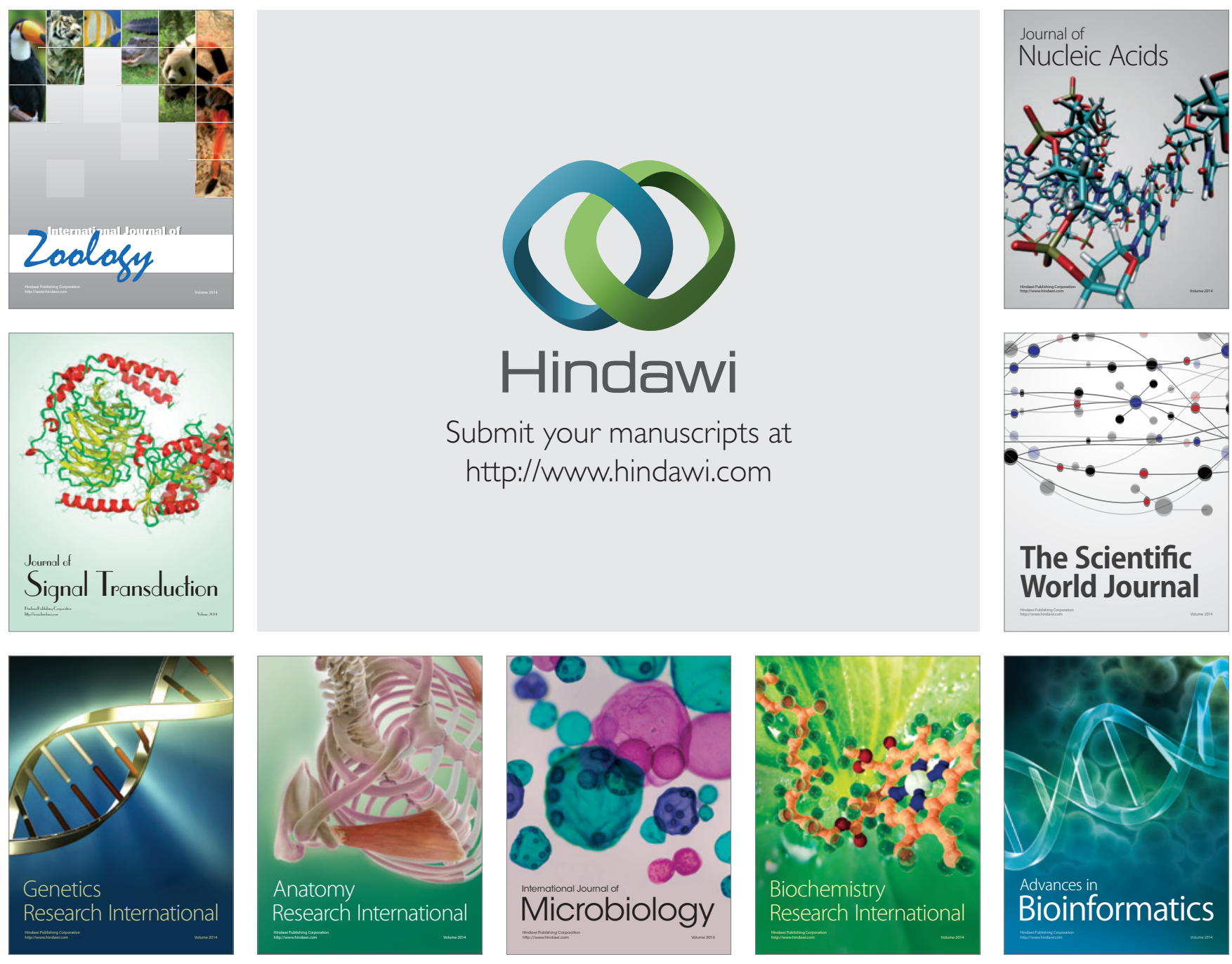

The Scientific World Journal
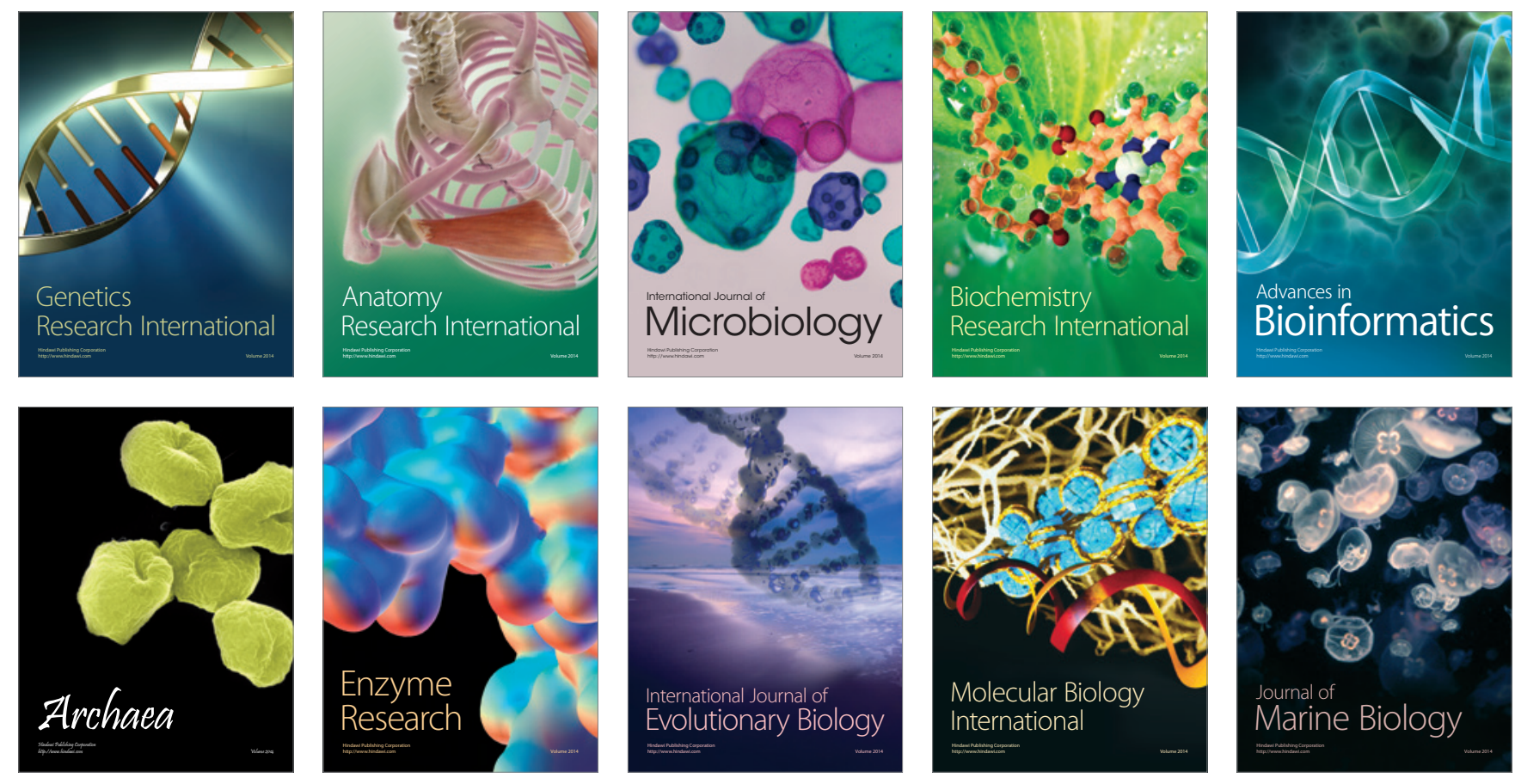